\title{
Sources and characteristics of size-resolved particulate organic acids and methanesulfonate in a coastal megacity: Manila, Philippines
}

\author{
Connor Stahl $^{1}$, Melliza Templonuevo Cruz ${ }^{2,3}$, Paola Angela Bañaga ${ }^{2,4}$, Grace Betito ${ }^{2,4}$, Rachel A. Braun ${ }^{1}$, \\ Mojtaba Azadi Aghdam ${ }^{1}$, Maria Obiminda Cambaliza ${ }^{2,4}$, Genevieve Rose Lorenzo ${ }^{2,5}$, Alexander B. MacDonald ${ }^{1}$, \\ Miguel Ricardo A. Hilario ${ }^{2}$, Preciosa Corazon Pabroa ${ }^{6}$, John Robin Yee $^{6}$, James Bernard Simpas ${ }^{2,4}$, and \\ Armin Sorooshian ${ }^{1,5}$ \\ ${ }^{1}$ Department of Chemical and Environmental Engineering, University of Arizona, Tucson, Arizona 85721, USA \\ ${ }^{2}$ Manila Observatory, Quezon City, 1108, Philippines \\ ${ }^{3}$ Institute of Environmental Science and Meteorology, University of the Philippines, Diliman, Quezon City, 1101, Philippines \\ ${ }^{4}$ Department of Physics, School of Science and Engineering, Ateneo de Manila University, Quezon City, 1108, Philippines \\ ${ }^{5}$ Department of Hydrology and Atmospheric Sciences, University of Arizona, Tucson, Arizona 85721, USA \\ ${ }^{6}$ Philippine Nuclear Research Institute - Department of Science and Technology, Commonwealth Avenue, \\ Diliman, Quezon City, 1101, Philippines
}

Correspondence: Connor Stahl (cstahl1@email.arizona.edu)

Received: 2 July 2020 - Discussion started: 27 July 2020

Revised: 31 October 2020 - Accepted: 31 October 2020 - Published: 21 December 2020

\begin{abstract}
A 16-month (July 2018-October 2019) dataset of size-resolved aerosol composition is used to examine the sources and characteristics of five organic acids (oxalate, succinate, adipate, maleate, phthalate) and methanesulfonate (MSA) in Metro Manila, Philippines. As one of the most polluted megacities globally, Metro Manila offers a view of how diverse sources and meteorology impact the relative amounts and size distributions of these species. A total of 66 sample sets were collected with a Micro-Orifice Uniform Deposit Impactor (MOUDI), of which 54 sets were analyzed for composition. Organic acids and MSA surprisingly were less abundant than in other global regions that are also densely populated. The combined species accounted for an average of $0.80 \pm 0.66 \%$ of total gravimetric mass between 0.056 and $18 \mu \mathrm{m}$, still leaving $33.74 \%$ of mass unaccounted for after considering black carbon and water-soluble ions and elements. The unresolved mass is suggested to consist of non-water-soluble metals as well as both water-soluble and non-water-soluble organics. Oxalate was approximately an order of magnitude more abundant than the other five species $\left(149 \pm 94 \mathrm{ng} \mathrm{m}^{-3}\right.$ versus others being $\left.<10 \mathrm{ng} \mathrm{m}^{-3}\right)$ across the $0.056-18 \mu \mathrm{m}$ size range. Both positive matrix factorization (PMF) and correlation analysis are conducted with tracer species to investigate the possible sources of organic
\end{abstract}

acids and MSA. Enhanced biomass burning influence in the 2018 southwest monsoon resulted in especially high levels of submicrometer succinate, MSA, oxalate, and phthalate. Peculiarly, MSA had negligible contributions from marine sources but instead was linked to biomass burning and combustion. Enhanced precipitation during the two monsoon seasons (8 June-4 October 2018 and 14 June-7 October 2019) coincided with a stronger influence from local emissions rather than long-range transport, leading to notable concentration enhancements in both the sub- and supermicrometer ranges for some species (e.g., maleate and phthalate). While secondary formation via gas-to-particle conversion is consistent with submicrometer peaks for the organic acids and MSA, several species (i.e., phthalate, adipate, succinate, oxalate) exhibited a prominent peak in the coarse mode, largely owing to their association with crustal emissions (i.e., more alkaline aerosol type) rather than sea salt. Oxalate's strong association with sulfate in the submicrometer mode supports an aqueous-phase formation pathway for the study region. However, high concentrations during periods of low rain and high solar radiation suggest photo-oxidation is an important formation pathway. 


\section{Introduction}

Organic acids are ubiquitous components of ambient particulate matter and can contribute appreciably to total mass concentrations in diverse regions ranging from the Arctic to deserts (e.g., Barbaro et al., 2017; Gao et al., 2003; Kawamura et al., 2005). Furthermore, another class of species contributing to ambient aerosol mass is organosulfur compounds, with methanesulfonate (MSA) being an example species (Bardouki et al., 2003b; Ding et al., 2017; Falkovich et al., 2005; Kerminen et al., 1999; Maudlin et al., 2015; Ziemba et al., 2011). The spatiotemporal and size-resolved mass concentration profiles of organic and sulfonic acids are difficult to characterize and can significantly vary depending on the time of day, season, region, and meteorological profile (Adam et al., 2020; Bagtasa et al., 2019; Kobayashi et al., 2004; Maudlin et al., 2015; Mochida et al., 2003; Reid et al., 2013). It is necessary to quantify their relative abundances and to understand factors affecting their production and eventual removal to be able to quantify their influence on aerosol hygroscopic and optical properties (Beaver et al., 2008; Cai et al., 2017; Freedman et al., 2009; Marsh et al., 2017, 2019; Myhre and Nielsen, 2004; Peng et al., 2016; Xue et al., 2009). Low-molecular-weight organic acids are water-soluble and can range widely in hygroscopicity when in their pure salt form depending on factors such as carbon number (Prenni et al., 2001; Saxena and Hildemann, 1996; Sorooshian et al., 2008) and interactions with other components in multicomponent aerosol particles (Drozd et al., 2014).

Organic acids are generally believed to effectively scatter light and have a cooling effect on climate (McGinty et al., 2009; Myhre and Nielsen, 2004), although their overall impact on properties such as refractive index in multicomponent aerosols is poorly characterized. Refractive indices for species investigated in this work range widely from 1.43 (MSA) to 1.62 (phthalic acid). MSA is assumed to be purely scattering, similar to sulfate (Hodshire et al., 2019), and to have hygroscopic properties close to those of ammonium sulfate (Asmi et al., 2010; Fossum et al., 2018). However, its hygroscopic and optical behavior is not fully understood and is still an active area of research (Liu et al., 2011; Peng and Chan, 2001; Tang et al., 2019, 2015; Zeng et al., 2014).

Decades of research into atmospheric organic acids and MSA have yielded rich insights into their sources, production mechanisms, and fate in the atmosphere (Baboukas et al., 2000; Bardouki et al., 2003a; Gondwe et al., 2004; Kawamura and Bikkina, 2016; Limbeck et al., 2001; Norton et al., 1983; Ovadnevaite et al., 2014; Sorooshian et al., 2009; van Pinxteren et al., 2015). MSA is produced predominantly from the oxidation of dimethylsulfide (DMS) emitted from oceans (Bates et al., 2004; Davis et al., 1998; Kerminen et al., 2017), but it also can be linked to biomass burning, urban, and agricultural emissions (Sorooshian et al., 2015). Sources of organic acids include primary emissions from biomass burning, biogenic activity, and the combustion of fossil fuels (Kawamura and Kaplan, 1987) and secondary formation via gas-to-particle conversion processes stemming from both biogenic (Carlton et al., 2006) and anthropogenic emissions (Sorooshian et al., 2007b). Secondary processing can include both aqueous-phase chemistry in clouds (Blando and Turpin, 2000; Ervens, 2018; Ervens et al., 2014; Hoffmann et al., 2019; Rose et al., 2018; Sareen et al., 2016; Warneck, 2005) and photo-oxidation of volatile organic compounds (VOCs) in cloud-free air (Andreae and Crutzen, 1997; Gelencsér and Varga, 2005). These various sources and production pathways result in mono- and dicarboxylic acids being prevalent across a range of aerosol sizes (Bardouki et al., 2003b; Kavouras and Stephanou, 2002; Neusüss et al., 2000; Yao et al., 2002). Little is reported in terms of the size-resolved nature of organic acids and MSA over long periods ( $>6$ months) of time with high sampling frequency (weekly or better). Although insights have already been gathered from size-resolved measurement studies (Table S1), most measurement reports are based on bulk mass concentration measurements (Chebbi and Carlier, 1996; Kawamura and Bikkina, 2016). Studying the seasonal variations of sizeresolved organic acid and MSA aerosols could prove vital in improved understanding of their formation and removal mechanisms and associated sensitivity to seasonally dependent sources and meteorological factors.

The Philippines is an important region to study aerosols due to the wide range of both meteorological conditions and diverse local and regional emissions sources (Alas et al., 2018; Bagtasa and Yuan, 2020; Braun et al., 2020; Hilario et al., 2020a; Kecorius et al., 2017). In addition to aerosol sources from nearby regions (Hilario et al., 2020b), the Philippines also has a significant source of local pollution, largely consisting of vehicular emissions due to high population density (Madueño et al., 2019), the use of outdated vehicles (Biona et al., 2017), ship exhaust from highdensity shipping lanes (Streets et al., 1997, 2000), and more lenient air regulations leading to significant air pollution due to rapid growth and urbanization (Alas et al., 2018; Kecorius et al., 2017). This leads to Metro Manila containing some of the highest black carbon (BC) concentrations in Southeast Asia and quite possibly the world (Alas et al., 2018; Hopke et al., 2011; Kecorius et al., 2017; Kim Oanh et al., 2006). Past aerosol characterization work for that region has focused mainly on gravimetric analysis of total bulk mass (e.g., $\mathrm{PM}_{2.5}, \mathrm{PM}_{10}$ ) (Bagtasa et al., 2018, 2019; Cohen et al., 2009; Kim Oanh et al., 2006), water-soluble inorganic and organic ion speciation (AzadiAghdam et al., 2019; Braun et al., 2020; Cruz et al., 2019; Kim Oanh et al., 2006; Simpas et al., 2014; Stahl et al., 2020a), and BC analysis (Alas et al., 2018; Bautista et al., 2014; Kecorius et al., 2017; Takahashi et al., 2014). In an analysis of two size-resolved aerosol sets in Manila, a significant portion of the total mass unaccounted for by the water-soluble inorganic, water-soluble organic, and BC components was attributed to (but not limited 
to) organics and non-water-soluble metals (Cruz et al., 2019). However, a concentrated effort to characterize the contributions of the water-soluble organic acids to the total aerosol mass in Manila over the course of a full year has not been undertaken.

The aim of this study is to use a 16-month-long dataset of size-resolved composition in Quezon City in Metro Manila to address the following questions: (i) how much do organic acids and MSA contribute to the region's aerosol mass concentrations? (ii) What are the seasonal differences in the mass size distribution profile of organic acids and MSA, and what drives the changes? (iii) What are the sources and predominant formation mechanisms of these species in the sub- and supermicrometer diameter ranges? The results of this study are put in broad context by comparing findings to those in other regions.

\section{Methods}

\subsection{Study site description}

Metro Manila is comprised of 16 cities and a municipality totaling a population of about 12.9 million people and a collective population density of $20800 \mathrm{~km}^{-2}$ (Alas et al., 2018; PSA, 2016). Quezon City is the most populated city in Metro Manila containing 2.94 million people with a population density of $18000 \mathrm{~km}^{-2}$ (PSA, 2016), which is among the highest in the world. Because of these reasons, Metro Manila is a fitting location for examining locally produced anthropogenic aerosols superimposed on a variety of other marine and continentally influenced air masses transported from upwind regions (Kim Oanh et al., 2006).

Measurements were conducted over a 16-month period between July 2018 and October 2019 at Manila Observatory $\left(\mathrm{MO} ; 14.64^{\circ} \mathrm{N}, 121.08^{\circ} \mathrm{E}\right)$ on the third floor ( $85 \mathrm{~m}$ a.s.1.) of an office building, which is on the Ateneo de Manila University campus in Quezon City, Philippines (Fig. 1). Sampling was conducted approximately $100 \mathrm{~m}$ away from the nearest road on campus, and therefore campus emissions do not impact sampling to a large degree, qualifying the monitoring site as an urban mixed background site (Hilario et al., 2020a) capturing local, regional, and long-range-transported emissions. The following four seasons were the focus of the sampling period: the 2018 southwest monsoon (SWM18, 8 June-4 October 2018) (PAGASA, 2018a, b), a transitional period (5-25 October 2018), the northeast monsoon (NEM, 26 October 2018-13 June 2019) (PAGASA, 2018c), and the 2019 southwest monsoon (SWM19, 14 June-7 October 2019) (PAGASA, 2019a, b). These seasons have also been defined in other works (i.e., Akasaka et al., 2007; Cruz et al., 2013; Matsumoto et al., 2020) and can predominately be separated into two general seasons, wet (SWM) and dry (NEM). Generally, there is a second transitional period in May that transitions between the NEM and SWM (Bagtasa and Yuan,
2020); however, recent studies suggest that the transition is abrupt (Matsumoto et al., 2020). Consequently, the second transitional period was combined with the NEM season.

\subsection{Instrument description}

Ambient aerosol was collected with a Micro-Orifice Uniform Deposit Impactor II (MOUDI II 120R, MSP Corporation; Marple et al. 2014) using Teflon substrates (PTFE membrane, $2 \mu \mathrm{m}$ pores, $46.2 \mathrm{~mm}$ diameter, Whatman). The MOUDI-II is a 10-stage impactor with aerodynamic cutpoint diameters $\left(D_{\mathrm{p}}\right)$ of $10,5.6,3.2,1.8,1.0,0.56,0.32,0.18,0.10$, and $0.056 \mu \mathrm{m}$, with a nominal flow rate of $\sim 30 \mathrm{~L} \mathrm{~min}^{-1}$. A total of 66 MOUDI sets were collected on a weekly basis, usually over a $48 \mathrm{~h}$ period; however, only 54 sets were analyzed for ions, and 47 of those sets were also analyzed for elements. A $48 \mathrm{~h}$ period was chosen because it offered an optimal compromise between gathering samples with fine temporal resolution and samples with a sufficiently large chemical signal to exceed analytical limits of detection. Details of the sample sets are shown in Table S2 and can be found in more detail in Stahl et al. (2020a), but a brief summary of the storage and extraction methods will be described here. Substrates were stored in a freezer at $-20^{\circ} \mathrm{C}$ after samples were collected from the MOUDI until extractions could be carried out, which on average was approximately 2 weeks. The stored substrates were then extracted by sonication in Milli$Q$ water $(18.2 \mathrm{M} \Omega \mathrm{cm}$ ) for $30 \mathrm{~min}$. After sonication, solutions were immediately analyzed to prevent degradation, while the remaining extracts were stored in a refrigerator for additional analyses. There have been studies that discuss the effects of sonication oxidation degrading organic species (i.e., Miljevic et al., 2014). It was determined through experimental tests that no significant degradation occurred during the sonication process for the species being analyzed in this study.

Water-soluble organic acids, MSA, and inorganic ions were speciated and quantified using ion chromatography (IC; Thermo Scientific Dionex ICS-2100 system), with a flow rate of $0.4 \mathrm{~mL} \mathrm{~min}^{-1}$. The anionic species of relevance to this study were MSA, chloride $\left(\mathrm{Cl}^{-}\right)$, nitrate $\left(\mathrm{NO}_{3}^{-}\right)$, sulfate $\left(\mathrm{SO}_{4}^{2-}\right)$, adipate, succinate, maleate, oxalate, and phthalate. These anions were resolved using potassium hydroxide (KOH) eluent, an AS11-HC $250 \mathrm{~mm}$ column, and an AERS 500e suppressor. The cationic species of relevance to this study was sodium $\left(\mathrm{Na}^{+}\right)$, which was detected using methanesulfonic acid eluent, a CS12A $250 \mathrm{~mm}$ column, and a CERS 500e suppressor. The IC instrument methods for anion and cation analysis can be found in Stahl et al. (2020a). Watersoluble elements were measured using a triple quadrupole inductively coupled plasma mass spectrometer (ICP-QQQ; Agilent 8800 Series). The quantified elements of relevance to this study include $\mathrm{Al}, \mathrm{As}, \mathrm{Cd}, \mathrm{K}, \mathrm{Ni}, \mathrm{Pb}, \mathrm{Rb}, \mathrm{Ti}$, and $\mathrm{V}$. Limits of detection (LOD) and recoveries were calculated for all ionic and elemental species and are provided in Table S3. Aside from the species that are the focus of this study (or- 
SWM18

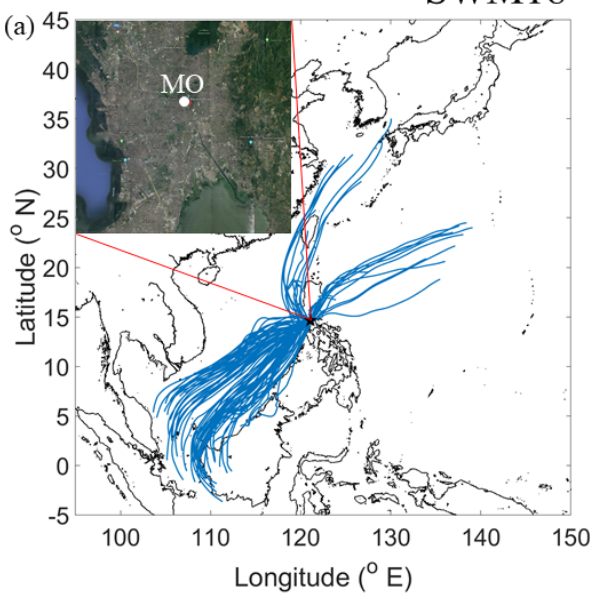

NEM

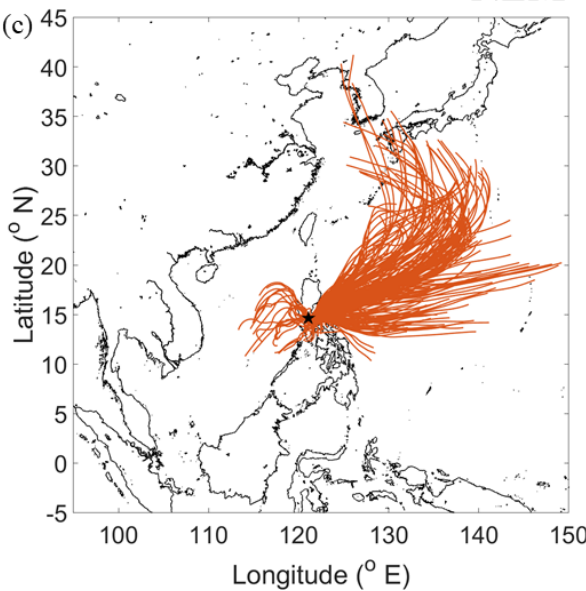

Transitional

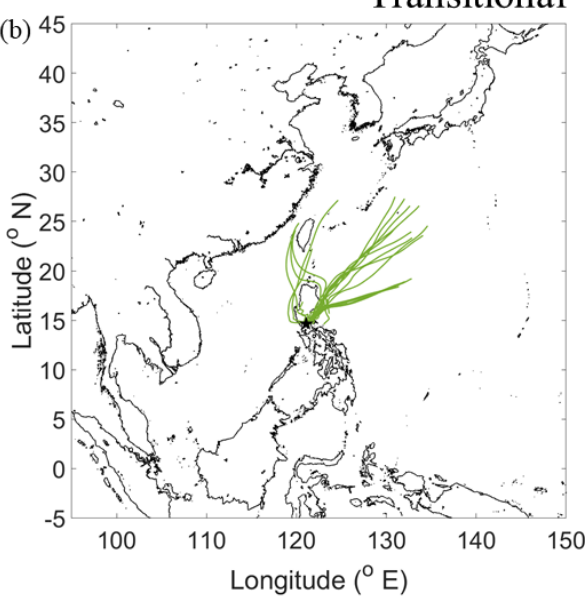

SWM19

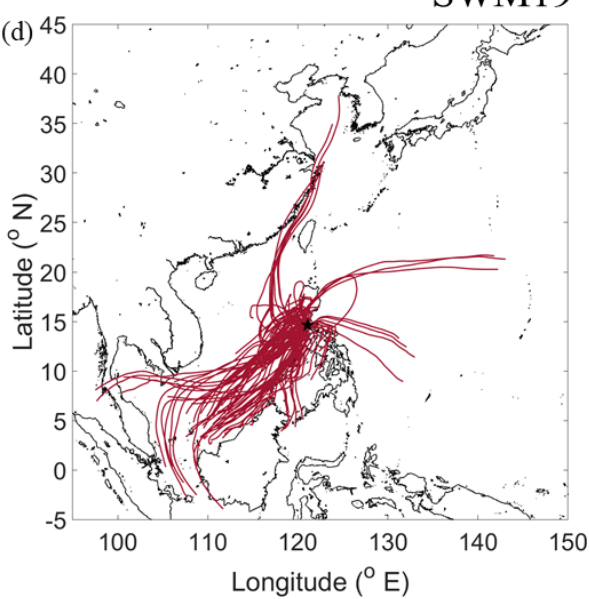

Figure 1. HYSPLIT back-trajectories for four seasons: (a) 2018 southwest monsoon (SWM18), (b) transitional period, (c) northeast monsoon (NEM), and (d) 2019 southwest monsoon (SWM19). Results shown are based on $72 \mathrm{~h}$ back-trajectories collected every $6 \mathrm{~h}$ during sampling periods. The top left corner of (a) zooms in on Metro Manila, with Manila Observatory (MO) marked. The black star in each panel represents the sampling site. Map data: () Google Earth, Maxar Technologies, CNES/Airbus, Data SIO, NOAA, U.S. Navy, NGA, GEBCO.

ganic acids and MSA), the other elements and ions were included as they are useful tracers for different aerosol sources to aid in source apportionment. Although pyruvate was speciated with IC, it is not considered with the other organic acids because it was below the LOD for 48 of the 54 sets. It should also be noted that only a subset of species used for analyses was listed here. The full suite of species can be seen in Stahl et al. (2020a).

A total of 11 of the 66 MOUDI sets included simultaneously operated MOUDI instruments next to each other to complement the chemical speciation analysis with gravimetric analysis. A Sartorius ME5-F microbalance (sensitivity of $\pm 1 \mu \mathrm{g}$ ) was used in an air-buffered room with controlled temperature $\left(20-23^{\circ} \mathrm{C}\right)$ and relative humidity (RH: $\left.30 \%-40 \%\right)$. Each substrate was passed near an antistatic tip for approximately $30 \mathrm{~s}$ to minimize bias due to electrostatic charge. Multiple weight measurements were conducted before and after sampling, with the difference between weighings be- ing less than $10 \mu \mathrm{g}$ for each condition, respectively. The difference between substrate weights before and after sampling was equated to total gravimetric mass.

Black carbon was measured using a Multi-wavelength Absorption Black Carbon Instrument (MABI; Australian Nuclear Science and Technology Organisation). The MABI optically quantifies black carbon concentrations by detecting the absorption at seven wavelengths $(405,465,525,639$, 870,940 , and $1050 \mathrm{~nm}$ ); however, the wavelength at $870 \mathrm{~nm}$ is used here as black carbon is the primary absorber at that wavelength (Cruz et al., 2019; Ramachandran and Rajesh, 2007; Ran et al., 2016).

Meteorological parameters were measured at MO during the study period using a Davis Vantage Pro2 ${ }^{\mathrm{TM}}$ Plus automatic weather station, which was located on the roof. Measured parameters of relevance included temperature, accumulated rain, RH, and solar radiation. Data were collected in $5 \mathrm{~min}$ increments and were cleaned based on the method 
of Bañares et al. (2018) to verify values were in acceptable ranges. The meteorological parameters, except for rain, were averaged over each sampling period, while rain was summed over time to obtain the accumulated precipitation for a sampling period. There were two periods during which the automatic weather station located at $\mathrm{MO}$ had missing values, 6 November-27 November 2018 and 7 August-3 September 2019. In these cases, missing values were substituted with values from a secondary automatic weather station located approximately $2 \mathrm{~km}$ away $\left(14.63^{\circ} \mathrm{N}, 121.06^{\circ} \mathrm{E}\right)$, and if missing data still persisted, a tertiary station located $5 \mathrm{~km}$ away $\left(14.67^{\circ} \mathrm{N}, 121.11^{\circ} \mathrm{E}\right)$ was used. Identical data cleaning procedures were implemented for the secondary and tertiary sites.

\subsection{Concentration weighted trajectories (CWTs)}

A CWT analysis was conducted to identify sources of detected species. The method assigns a weighted concentration to a grid that is calculated by finding the mean of sample concentrations that have trajectories crossing a particular cell in the grid (e.g., Dimitriou, 2015; Dimitriou et al., 2015; Hilario et al., 2020a; Hsu et al., 2003). The software TrajStat (Wang et al., 2009) determines CWT profiles by using back-trajectories from the NOAA Hybrid Single-Particle Lagrangian Integrated Trajectory (HYSPLIT) model (Rolph et al., 2017; Stein et al., 2015). Using the Global Data Assimilation System (GDAS) and the model vertical velocity method, $3 \mathrm{~d}$ back-trajectories were obtained with an ending altitude of $500 \mathrm{~m}$ a.g.l. The choice of $500 \mathrm{~m}$ is based on representativeness of the mixed layer and it having been widely used in other studies (e.g., Crosbie et al., 2014; Mora et al., 2017; Sorooshian et al., 2011). Trajectories were obtained every $6 \mathrm{~h}$ after MOUDI sampling began for each sample set, yielding approximately nine trajectories per set. A grid domain of 95 to $150^{\circ} \mathrm{E}$ longitude and -5 to $45^{\circ} \mathrm{N}$ latitude was used, with a grid cell resolution of $0.5^{\circ} \times 0.5^{\circ}$. The analysis was performed for each measured organic acid and MSA for the full diameter range of MOUDI sets $(0.056-18 \mu \mathrm{m})$. A weighting function was applied to the CWT plots to minimize uncertainty.

\subsection{Positive matrix factorization (PMF)}

PMF analysis was applied to identify sources and their relative importance for the mass concentration budgets of the species discussed in this work (Paatero and Tapper, 1994). Model simulations were conducted based on MOUDI data for the diameter range of $0.056-18 \mu \mathrm{m}$. A total of 19 species (Al, Ti, K, $\mathrm{Rb}, \mathrm{V}, \mathrm{Ni}, \mathrm{As}, \mathrm{Cd}, \mathrm{Pb}, \mathrm{Na}^{+}, \mathrm{Cl}^{-}, \mathrm{NO}_{3}^{-}, \mathrm{SO}_{4}^{2-}$, MSA, adipate, succinate, maleate, oxalate, and phthalate) were included in the analysis and categorized as "strong". Each individual stage of MOUDI sets was considered an independent variable for the analysis. Missing values or values below the detection limit were replaced with zeros, with the exception of sets for which ICP-QQQ analysis was not performed $(57,59,60,61,62,64,65)$. These missing values were replaced with the geometric mean for each respective stage. The uncertainty for each stage and species was calculated as follows:

Uncertainty $=0.05 \times[x]+\mathrm{LOD}$,

where $[x]$ is the concentration of the species (Reff et al., 2007). No additional uncertainty was added to account for any unconsidered errors for all species. The uncertainty of the model output was evaluated using displacement (DISP), bootstrapping (BS), and bootstrapping with displacement (BS-DISP). For BS, 100 resamples were used, and a value of 0.6 was used as a threshold for the correlation coefficient $(r)$ to pass as successful mapping for each simulation.

To qualify as a valid result, reported PMF results had to meet the following criteria: (i) factors are mapped with BS runs, (ii) there are no factor swaps in DISP, (iii) displacements from its fitted values (dQ) are close or equal to $0 \%$, and (iv) there are no factor swaps in BS-DISP, where $\mathrm{Al}, \mathrm{Ti}$, $\mathrm{K}, \mathrm{Rb}, \mathrm{V}, \mathrm{Ni}, \mathrm{As}, \mathrm{Cd}, \mathrm{Pb}, \mathrm{Na}^{+}, \mathrm{Cl}^{-}, \mathrm{NO}_{3}^{-}$, and $\mathrm{SO}_{4}^{2-}$ were displaced. PMF diagnostics can be seen in Table $\mathrm{S} 4$ based on the method of Brown et al. (2015).

\section{Background on measured acids}

A brief overview of the species being examined is first provided before reviewing concentration statistics. MSA is an oxidation product of dimethylsulfide (DMS) emitted primarily from the ocean (Berresheim, 1987; Saltzman et al., 1983), but it can also be formed from dimethyl sulfoxide (DMSO) emitted from anthropogenic sources such as industrial waste (Yuan et al., 2004). Gaseous MSA can become associated with particulate matter via new particle formation (Dawson et al., 2012) and through heterogeneous reactions or condensation onto existing particles (De Bruyn et al., 1994; Hanson, 2005).

Of the three saturated dicarboxylic acids, succinate $\left(\mathrm{C}_{4}\right)$ and adipate $\left(\mathrm{C}_{6}\right)$ are larger chain dicarboxylic acids linked to ozonolysis of cyclic alkenes, which is common in areas with extensive vehicular emissions (Grosjean et al., 1978; Hatakeyama et al., 1987). They can also be emitted via processes such as meat cooking (Rogge et al., 1993) and biomass burning (Kawamura et al., 2013; Pereira et al., 1982) and can be secondarily formed by the photo-oxidation of higher chain organic acids, such as azelaic acid (Bikkina et al., 2014; Ervens et al., 2004). Oxalate $\left(C_{2}\right)$ is the smallest of the three acids and is usually the most abundant on a mass basis of all dicarboxylic acids in tropospheric aerosols as it represents an end product in the oxidation of both larger-chain carboxylic acids and also glyoxylic acid (Ervens et al., 2004). It can be emitted via direct emissions such as from biomass burning (Graham et al., 2002; Narukawa et al., 1999; Xu et al., 2020) and combustion exhaust (Kawamura and Ka- 
plan, 1987; Kawamura and Yasui, 2005; Wang et al., 2010) and from various biogenic sources (Kawamura and Kaplan, 1987).

Maleate $\left(\mathrm{C}_{4}\right)$ is an unsaturated dicarboxylic acid originating from combustion engines, including via direct emissions (Kawamura and Kaplan, 1987) and secondarily produced from the photo-oxidation of benzene (Rogge et al., 1993). Lastly, phthalate $\left(\mathrm{C}_{8}\right)$ represents an aromatic dicarboxylic acid associated with incomplete combustion of vehicular emissions (Kawamura and Kaplan, 1987) and oxidation of naphthalene or other polycyclic aromatic hydrocarbons (Fine et al., 2004; Kawamura and Ikushima, 2002; Kawamura and Yasui, 2005). However, it has also been linked to biomass burning (Kumar et al., 2015) and burning of plastic material such as polyvinyl chloride (PVC) products, garbage, and plastic bags (Agarwal et al., 2020; Claeys et al., 2012; Fu et al., 2012; Li et al., 2019; Nguyen et al., 2016; Simoneit et al., 2005). Secondary formation via aqueous-phase chemistry has been documented for these organic acids (Kunwar et al., 2019; Sorooshian et al., 2007a, 2010, 2006; Wonaschuetz et al., 2012) and MSA (Hoffmann et al., 2016).

\section{Results}

\subsection{Meteorology and transport patterns}

Meteorological data are summarized based on average values temporally coincident with each MOUDI sample set period for each of the seasons. The exception to this was the accumulated rainfall, which was summed for the MOUDI set duration. Temperatures were stable during the different seasons: $28.0 \pm 1.04^{\circ} \mathrm{C}$ (SWM18), $28.9 \pm 0.8^{\circ} \mathrm{C}$ (transitional), $28.3 \pm 1.9^{\circ} \mathrm{C}$ (NEM), and $28.4 \pm 1.5^{\circ} \mathrm{C}$ (SWM19). Solar radiation was the highest during the transitional $\left(279.61 \pm 19.68 \mathrm{~W} \mathrm{~m}^{-2}\right)$ and NEM $\left(304.01 \pm 67.54 \mathrm{~W} \mathrm{~m}^{-2}\right)$ seasons and lowest during the SWM18 $\left(225.32 \pm 56.26 \mathrm{~W} \mathrm{~m}^{-2}\right)$ and SWM19 $\left(256.05 \pm 86.88 \mathrm{~W} \mathrm{~m}^{-2}\right)$ seasons, owing largely to more cloud cover. Accumulated rain was highest for both SWM seasons (SWM18: $29.78 \pm 27.28 \mathrm{~mm}$; SWM19: $16.66 \pm 23.98 \mathrm{~mm}$ ) and much lower during the transitional $(1.00 \pm 1.11 \mathrm{~mm})$ and NEM $(2.20 \pm 6.70 \mathrm{~mm})$ seasons. Relative humidity was relatively consistent across seasons: SWM18 $(69.6 \pm 5.0 \%)$, transitional $(69.2 \pm 2.2 \%)$, NEM season $(62.4 \pm 8.0 \%)$, SWM19 (72.6 $\pm 11.7 \%)$. Finally, Fig. 1 summarizes predominant wind patterns for each season based on HYSPLIT back-trajectories collected every $6 \mathrm{~h}$ during sampling periods. The SWM18 and SWM19 seasons were characterized by predominantly southwesterly winds, while the NEM and transitional seasons experienced mostly northeasterly winds. In conclusion, there was much higher potential for wet scavenging during the SWM seasons, with the potential for more photochemical reactivity in the NEM and transitional seasons owing to enhanced incident solar

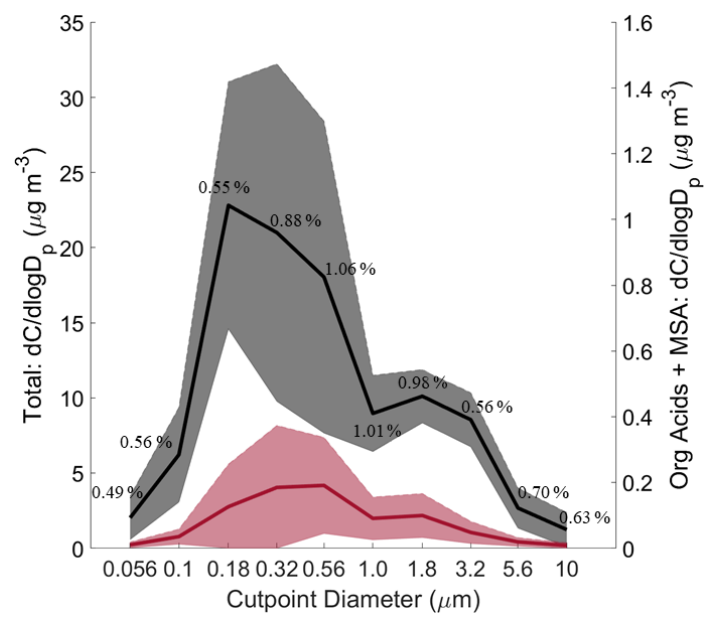

Figure 2. Size-resolved comparison of total mass versus the sum of measured organic acids and MSA. The black curve represents total mass, and the red curve represents the summed organic acids and MSA. Solid lines are the averages, and shaded areas are 1 standard deviation. These plots were made based on data from the 11 MOUDI chemical sets with accompanying gravimetric measurements. The average percent contribution of the organic acids and MSA to total mass is provided for each size bin. Refer to Fig. S1 for the seasonally resolved version of this figure.

radiation. As humidity was generally enhanced year round, there was the likelihood of aqueous-phase processing to occur in all seasons. The combination of sustained $\mathrm{RH}$, low boundary layer height, and high surface-level particle concentrations has been suggested to counteract the effects of wet deposition on total particle concentration in Metro Manila (Hilario et al., 2020a).

\subsection{Bulk aerosol measurements}

The range, mean, and standard deviation of concentrations integrated across the MOUDI diameter range (0.056$18 \mu \mathrm{m})$ are shown in Table 1 for each organic acid and MSA for all seasons. In order of decreasing concentration, the following was the order of abundance based on the cumulative dataset: oxalate $\left(149 \pm 94 \mathrm{ng} \mathrm{m}^{-3}\right)$ $>$ succinate $\left(10 \pm 22 \mathrm{ng} \mathrm{m}^{-3}\right)>$ maleate $\left(10 \pm 20 \mathrm{ng} \mathrm{m}^{-3}\right)$ $>$ phthalate $\left(9 \pm 14 \mathrm{ng} \mathrm{m}^{-3}\right)>$ adipate $\left(7.6 \pm 9.4 \mathrm{ng} \mathrm{m}^{-3}\right)$ $>$ MSA $\left(5.4 \pm 5.2 \mathrm{ng} \mathrm{m}^{-3}\right)$. The relative order of abundance varies for the sub- and supermicrometer ranges, with the only consistent feature being that oxalate was the most abundant species. This result was consistent with past works showing oxalate to be the most abundant organic acid in different global regions (e.g., Decesari et al. 2006; Kerminen et al. 1999; Sorooshian et al. 2007b; Ziemba et al. 2011).

Figure 2 shows the combined contribution of the organic acids and MSA to total gravimetric mass, while Table S5 summarizes percent contributions of individual species to total mass for different size bins. Combined, 


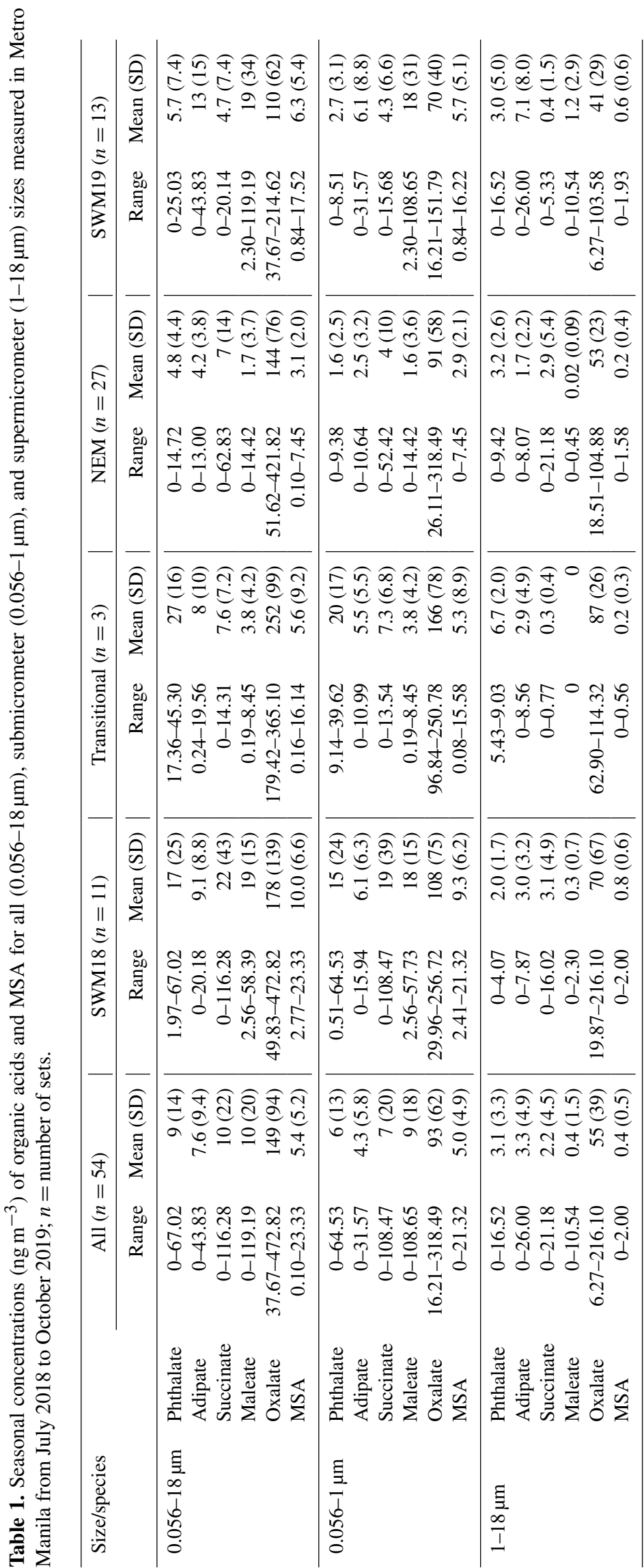


the measured organic acids and MSA accounted for only a small part of the total cumulative mass $(0.80 \pm 0.66 \%)$ across the 11 individual gravimetric sets. When the combined contribution of organic acids and MSA to total gravimetric mass was separated by season, results are generally the same (Fig. S1), with differences in the percent range being as follows: SWM18 $=0.64 \%$; transitional $=0.95 \%$; $\mathrm{NEM}=0.50 \%-1.49 \%$; and $\mathrm{SWM} 19=0.23 \%-0.83 \%$. The highest contribution of these organic acids and MSA occurred for MOUDI sets collected 12-14 March 2019 during the NEM season, which accounted for $1.49 \%\left(0.50 \mu \mathrm{g} \mathrm{m}^{-3}\right)$ of the total mass. The lowest contribution of these organic acids and MSA occurred for MOUDI sets collected 11-13 September 2019 during the SWM19 season, which accounted for $0.23 \%\left(0.06 \mu \mathrm{g} \mathrm{m}^{-3}\right)$ of the total mass. The summed contributions of the six species were nearly the same in the sub- and supermicrometer ranges $(0.78 \pm 0.74 \%$ and $0.84 \pm 0.58 \%$, respectively). Their contributions peaked in the two size bins covering the range between 0.56 and $1.8 \mu \mathrm{m}(0.56-1 \mu \mathrm{m}: 1.06 \pm 1.01 \%$; $1-$ $1.8 \mu \mathrm{m}: 1.01 \pm 0.78 \%)$. After accounting for all measured species (BC, water-soluble species), $33.74 \pm 19.89 \%$ (range: $23.86 \%-50.88 \%$ ) of unresolved mass still remained. Therefore, the six species of interest in this work only explain a small amount of the region's mass concentrations, and further work is still needed to resolve the remaining components, which presumably are dominated by water-insoluble organics and elements. Of most need is to resolve those missing components in the supermicrometer range, for which Table S5 shows that the unresolved fraction is $69.10 \pm 25.91 \%$, in contrast to $17.78 \pm 17.25 \%$ for the submicrometer range.

Although there are fairly wide ranges in concentration for the individual species, a few features are noteworthy based on the cumulative dataset. First, the oxalate concentrations are lower than expected for such a highly polluted area, as will be expanded upon in Sect. 5.5. Second, there is a significant decrease in concentration after oxalate for the remaining five species, which had similar mean concentrations. Lastly, although the sampling site is on an island and close to marine sources, MSA is surprisingly the least abundant among the six species of interest.

Mean mass concentrations of these species varied greatly by season as visually shown in Fig. 3a and summarized numerically in Table 1 . In contrast, Fig. $3 b$ shows that the mass fractions of the six species did not change much seasonally, owing to the dominance of oxalate (37.67-472.82 $\mathrm{ng} \mathrm{m}^{-3}$ ), which accounted for between $69.1 \%-87.3 \%$ of the cumulative concentration of the six species across the four seasons. Important features with regard to seasonal mass concentration differences include the following: (i) maleate concentrations were much higher in the SWM18 and SWM19 seasons; (ii) the lowest overall concentrations of most species, besides oxalate and succinate (lowest in SWM19), were observed in the NEM season; (iii) oxalate and phthalate were the only species that peaked in the transitional period, whereas the
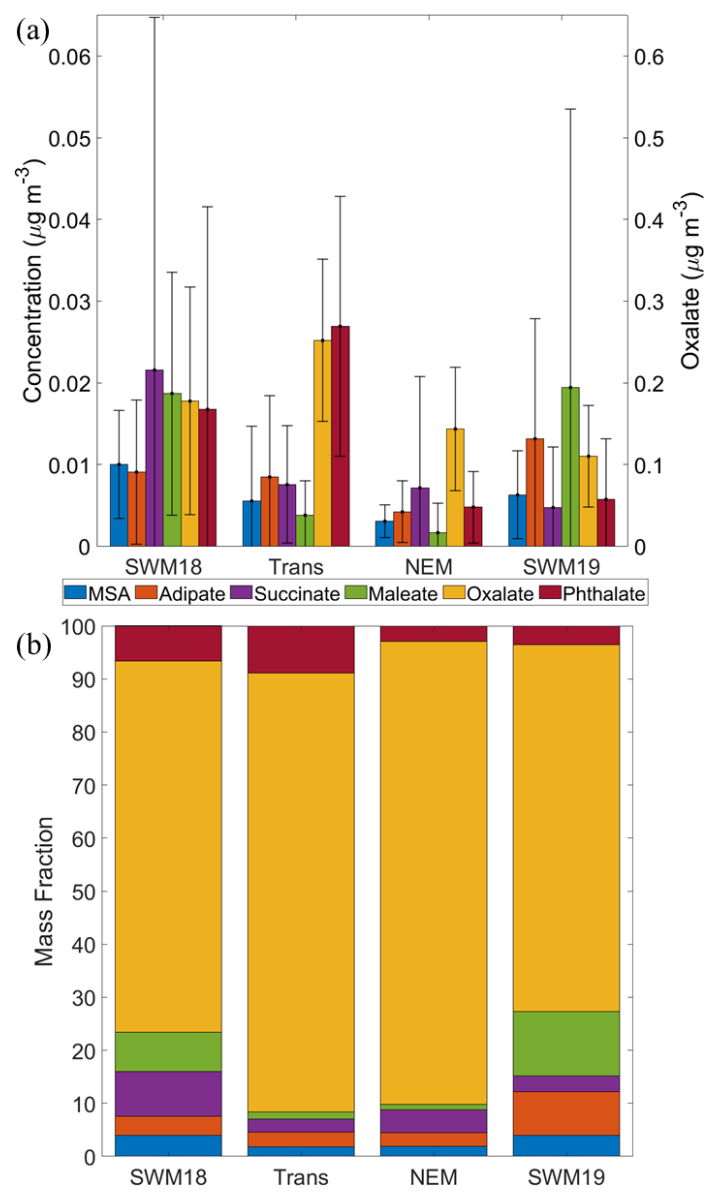

Figure 3. (a) Average concentrations $(0.056-18 \mu \mathrm{m})$ for (left $y$ axis) MSA, adipate, succinate, maleate, and phthalate, in addition to (right $y$ axis) oxalate. Black bars represent 1 standard deviation. (b) Percentage relative mass abundance of organic acids and MSA separated based on season.

rest of the species peaked in either SWM18 or SWM19; and (iv) succinate and phthalate were peculiarly much more enhanced in SWM18 than SWM19, pointing to significant variability between consecutive years.

\subsection{Source apportionment}

To help elucidate how different emissions sources impact the six species, PMF analysis was conducted and yielded a solution with five source factors using year-round data (Fig. 4). The five sources are as follows in decreasing order of their contribution to the total mass based on the sum of species used in the PMF analysis (Fig. 4): combustion (32.1\%), biomass burning (20.9\%), sea salt (20.9\%), crustal $(14.2 \%)$, and waste processing $(11.9 \%)$. The contribution of each source to the total concentration of organic acids and MSA was as follows: combustion (33.5\%), biomass burning $(29.0 \%)$, crustal $(27.0 \%)$, waste processing $(9.8 \%)$, and sea salt $(0.6 \%)$. The source factor names were determined 


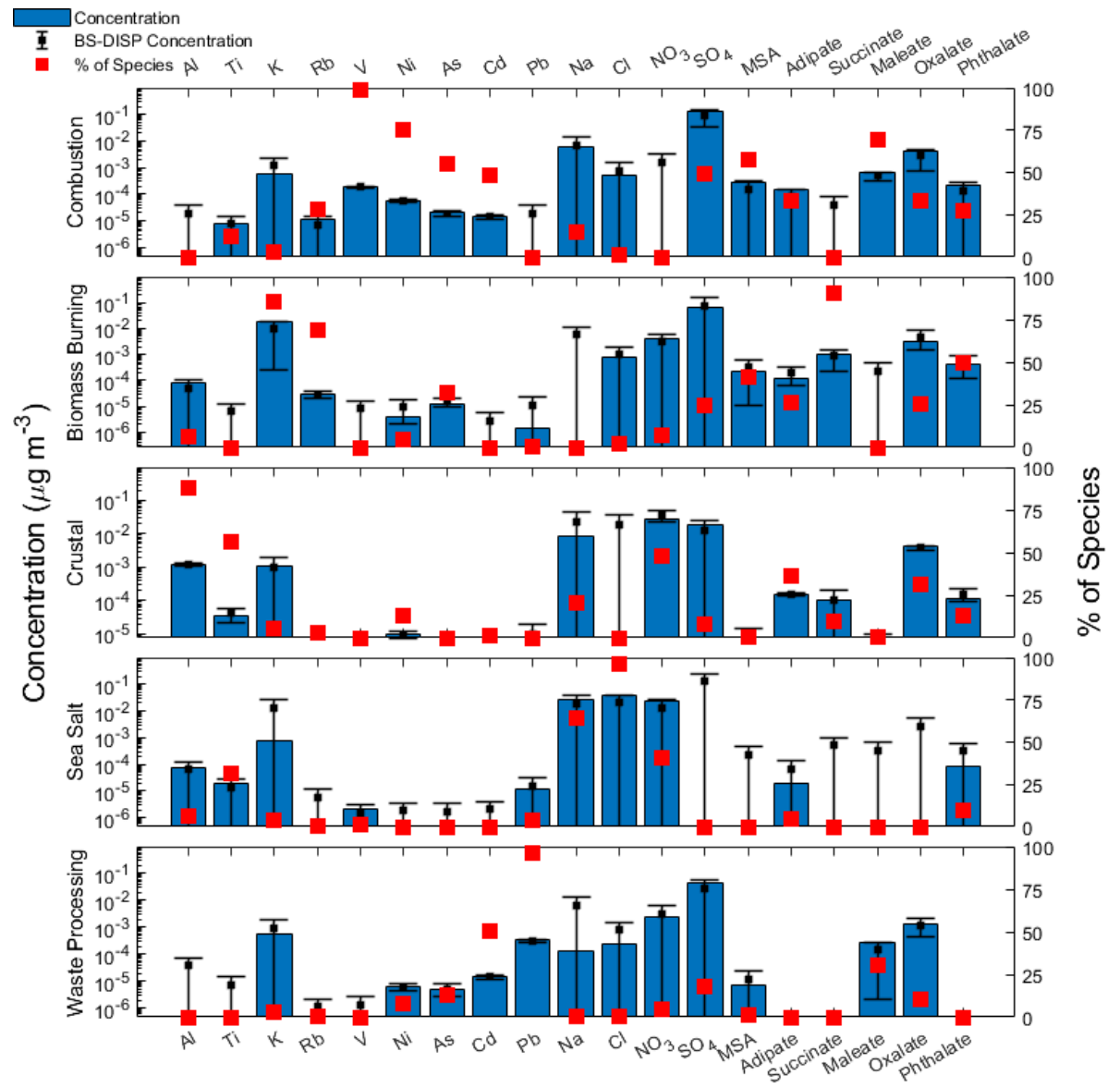

Figure 4. Source factor profiles from positive matrix factorization (PMF) analysis. Blue bars represent the mass concentration contributing to the respective factor, red filled squares represent the percentage of total species associated with that source factor, and black squares with error bars represent the average, 5th, and 95th percentiles of bootstrapping with displacement (BS-DISP) values.

based on the enhancement of the following species (Fig. 4): (i) crustal (Al, Ti) (Harrison et al., 2011; Malm et al., 1994; Singh et al., 2002); (ii) biomass burning (K, Rb) (Andreae, 1983; Artaxo et al., 1994; Braun et al., 2020; Chow et al., 2004; Echalar et al., 1995; Ma et al., 2019; Schlosser et al., 2017; Thepnuan et al., 2019; Yamasoe et al., 2000); (iii) sea salt (Na, Cl) (Seinfeld and Pandis, 2016); (iv) combustion (V, Ni, As) (Allen et al., 2001; Linak et al., 2000; Mahowald et al., 2008; Mooibroek et al., 2011; Prabhakar et al., 2014; Wasson et al., 2005); and (v) waste processing (Cd, $\mathrm{Pb}$ ) (Cruz et al., 2019; Gullett et al., 2007; Iijima et al., 2007; Pabroa et al., 2011). While both $\mathrm{SO}_{4}^{2-}$ and $\mathrm{NO}_{3}^{-}$are secondarily produced, the latter is more commonly linked to supermicrometer particles (Allen et al., 1996; Dasgupta et al., 2007; Fitzgerald, 1991; Maudlin et al., 2015), including in the study region (Cruz et al., 2019). Additionally, Al, K, and $\mathrm{Cl}$ are linked to biomass burning (Reid et al., 1998, 2005; Schlosser et al., 2017; Wonaschütz et al., 2011). The source factor names should be interpreted with caution, as a single profile may consist of a mix of sources (e.g., waste processing). It should be noted that Cruz et al. (2019) performed

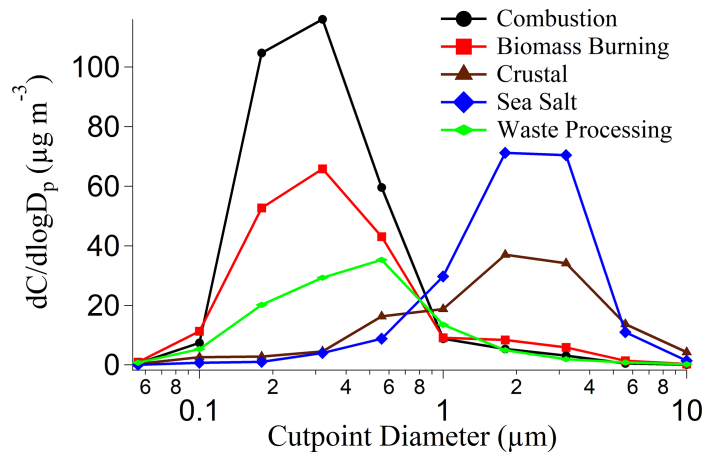

Figure 5. Reconstructed mass size distributions of positive matrix factorization (PMF) factors.

PMF analysis for only the SWM18 season, which yielded similar and additional sources for only the SWM18 season, whereas this study used year-round data.

To provide a size-resolved context for the five aerosol sources, Fig. 5 shows their respective reconstructed mass size distributions based on PMF output. Distributions for com- 
Table 2. Contributions of the five positive matrix factorization (PMF) source factors to each individual organic acid and MSA.

\begin{tabular}{lrrrrr}
\hline & Combustion & $\begin{array}{r}\text { Biomass } \\
\text { burning }\end{array}$ & Crustal & $\begin{array}{r}\text { Sea } \\
\text { salt }\end{array}$ & $\begin{array}{r}\text { Waste } \\
\text { processing }\end{array}$ \\
\hline Phthalate & $27.4 \%$ & $49.5 \%$ & $13.3 \%$ & $9.9 \%$ & $0 \%$ \\
Adipate & $32.9 \%$ & $26.4 \%$ & $35.9 \%$ & $4.7 \%$ & $0 \%$ \\
Succinate & $0 \%$ & $90.3 \%$ & $9.7 \%$ & $0 \%$ & $0 \%$ \\
Maleate & $69.7 \%$ & $0 \%$ & $0.2 \%$ & $0 \%$ & $30.1 \%$ \\
Oxalate & $32.9 \%$ & $25.4 \%$ & $31.2 \%$ & $0 \%$ & $10.5 \%$ \\
MSA & $57.4 \%$ & $41.2 \%$ & $0.1 \%$ & $0 \%$ & $1.4 \%$ \\
\hline
\end{tabular}

bustion, biomass burning, and waste processing primarily peaked in the submicrometer range, while crustal and sea salt sources primarily peaked in the supermicrometer range. Combustion and biomass burning factors showed a dominant peak between $0.32-0.56 \mu \mathrm{m}$, whereas waste processing had a peak between $0.56-1 \mu \mathrm{m}$. The crustal and sea salt factors exhibited their peak concentrations between 1.8-5.6 $\mu \mathrm{m}$. Both crustal and biomass burning sources showed signs of bimodal size distributions, with a minor peak in the sub- and supermicrometer ranges, respectively.

As reported in Table 2, combustion was the largest contributor to the cumulative mass concentrations of organic acids and MSA, with the largest influence being for maleate $(69.7 \%)$ and MSA (57.4\%). Biomass burning was marked by its significant contribution to succinate $(90.3 \%)$. The sea salt source showed minor contributions to phthalate $(9.9 \%)$ and adipate $(4.7 \%)$. The crustal source contributed appreciably to adipate $(35.9 \%)$ and oxalate $(31.2 \%)$, with the rest of the organic acid or MSA species being less influenced $(0.1 \%-13.3 \%)$. Organic acids have been shown in past work to be associated with mineral dust (Russell et al., 2002), including both oxalic and adipic acids (Falkovich et al., 2004; Kawamura et al., 2013; Sullivan and Prather, 2007; Tsai et al., 2014), although less has been documented for adipate. Wang et al. (2017) and Yao et al. (2003) both report that gaseous acids are likely to adsorb onto supermicrometer particles that are highly alkaline, such as dust. The waste processing factor contributed to maleate $(30.1 \%)$, oxalate $(10.5 \%)$, and MSA $(1.4 \%)$. An unexpected result was that the sea salt factor did not contribute to MSA, even though the latter is derived from ocean-emitted DMS; the results of Table 2 suggest that other sources such as biomass burning and industrial activities are more influential in the study region, similar to other regions like Beijing (Yuan et al., 2004) and coastal and inland areas of California (Sorooshian et al., 2015).

\subsection{Species interrelationships}

Correlation analysis was conducted for the same species used in the PMF analysis to quantify interrelationships and to gain additional insight into common production pathways. Correlation coefficient $(r)$ values are reported in Table 3 for the sub- and supermicrometer ranges, whereas results for the full size range are shown in Table S6. Values are only shown and discussed subsequently for correlations with $p$ values below 0.05 . Unless otherwise stated, correlations discussed below correspond to the full size range for simplicity, whereas notable results when contrasting the two size ranges $(<1 \mu \mathrm{m}$ and $<1 \mu \mathrm{m}$ ) are explicitly mentioned.

MSA exhibited a statistically significant correlation with $\mathrm{Rb}(r=0.37)$, suggestive of its link with biomass burning as $\mathrm{Rb}$ has been shown in the study region to be a biomass burning marker (Braun et al., 2020). Additionally, MSA was correlated with $\mathrm{Na}, \mathrm{NO}_{3}^{-}$, and $\mathrm{SO}_{4}^{2-}(r: 0.35-0.59)$, which are associated with marine aerosol (e.g., sea salt, DMS, shipping) but also biomass burning. The supermicrometer results indicate MSA was correlated only with $\mathrm{Na}(r=0.32)$, due presumably to co-emission from both crustal and sea salt sources, with the former commonly linked to biomass burning (Schlosser et al., 2017). For the submicrometer range, MSA was correlated with $\mathrm{Rb}$ and $\mathrm{SO}_{4}^{2-}$ ( $\left.r: 0.39-0.60\right)$, which are derived from biomass burning and other forms of combustion, consistent with smaller particles formed secondarily from gas-to-particle conversion processes. That is also why MSA was well correlated with succinate, oxalate, and phthalate $(r: 0.53-0.67)$, which were also prominent species in either (or both) of the biomass burning and combustion factors.

Adipate only exhibited significant correlations with maleate and phthalate for the full diameter range $(r: 0.43-$ 0.45 ), while maleate was correlated only with adipate. In contrast, succinate, oxalate, and phthalate were correlated with a wide suite of species, indicating that maleate and adipate exhibited more unique behavior in terms of their production routes. Succinate, oxalate, and phthalate similarly exhibited significant correlations with each other and species linked to crustal sources (Al, Ti, Na), sea salt $(\mathrm{Na})$, and biomass burning $(\mathrm{Rb})$. Succinate and oxalate in particular were better correlated with tracer species related to either dust or sea salt (Al, Na) in the supermicrometer range and were correlated with each other also in that size range.

\subsection{Cumulative size distribution variations}

Mass size distributions for each individual organic acid and MSA are shown for the full study period in Fig. S2, and seasonal mass size distributions can be seen in Figs. 6-11. General information for the cumulative dataset will be described here before examining seasonal results in Sect. 5 . While significant variability exists between individual sets for the cumulative dataset, a few general features are evident: (i) mass size distributions all appear multimodal with the exception of maleate, which on average exhibited a unimodal profile; (ii) all species show a larger peak in the submicrometer range versus supermicrometer sizes; (iii) phthalate and adipate show more comparable peaks in the sub- and supermicrometer range; and (iv) the size bin in which the peaks 
Table 3. Pearson's correlation matrices ( $r$ values) of water-soluble species for submicrometer $(0.056-1.0 \mu \mathrm{m})$ and supermicrometer $(1.0-$ $18 \mu \mathrm{m})$ sizes. Blank boxes indicate $p$ values exceeding 0.05 and thus deemed to be statistically insignificant. Ad - adipate, Su - succinate, $\mathrm{Ma}$ - maleate, $\mathrm{Ox}$ - oxalate, $\mathrm{Ph}$ - phthalate. A similar correlation matrix for the full size range $(0.056-18 \mu \mathrm{m})$ is in Table $\mathrm{S} 6$.

\begin{tabular}{|c|c|c|c|c|c|c|c|c|c|c|c|c|c|c|c|c|c|c|c|}
\hline$<1 \mu \mathrm{m}$ & & & & & & & & & & & & & & & & & & & \\
\hline Al & 1.00 & & & & & & & & & & & & & & & & & & \\
\hline $\mathrm{Ti}$ & & 1.00 & & & & & & & & & & & & & & & & & \\
\hline $\mathbf{K}$ & 0.91 & & 1.00 & & & & & & & & & & & & & & & & \\
\hline $\mathbf{R b}$ & 0.44 & & 0.48 & 1.00 & & & & & & & & & & & & & & & \\
\hline V & & 0.28 & & 0.36 & 1.00 & & & & & & & & & & & & & & \\
\hline $\mathbf{N i}$ & & \begin{tabular}{|l|}
0.47 \\
\end{tabular} & & 0.40 & 0.89 & 1.00 & & & & & & & & & & & & & \\
\hline As & & & & & & & 1.00 & & & & & & & & & & & & \\
\hline Cd & & & & & 0.64 & 0.68 & & 1.00 & & & & & & & & & & & \\
\hline $\mathbf{P b}$ & 0.41 & & \begin{tabular}{|l|}
0.32 \\
\end{tabular} & 0.27 & 0.28 & 0.40 & & 0.42 & 1.00 & & & & & & & & & & \\
\hline $\mathrm{Na}$ & & & & & & & & & & 1.00 & & & & & & & & & \\
\hline $\mathrm{Cl}$ & 0.90 & & 0.99 & 0.39 & & & & & 0.30 & & 1.00 & & & & & & & & \\
\hline NO3 & 0.76 & & \begin{tabular}{|l|l|}
0.82 \\
\end{tabular} & 0.28 & & & & & & & 0.84 & 1.00 & & & & & & & \\
\hline SO4 & & & & \begin{tabular}{|l|}
0.42 \\
\end{tabular} & \begin{tabular}{|l|}
0.48 \\
\end{tabular} & 0.40 & & & & & & & 1.00 & & & & & & \\
\hline MSA & & & & 0.39 & & & & & & & & & 0.60 & 1.00 & & & & & \\
\hline Ad & & & & & & & & & & & & & & & 1.00 & & & & \\
\hline Su & & 0.31 & & 0.67 & & & & & & & & & 0.45 & 0.67 & \begin{tabular}{|l|l}
0.33 \\
\end{tabular} & 1.00 & & & \\
\hline Ma & & & & & & & & & & & & & & & \begin{tabular}{|l|}
0.32 \\
\end{tabular} & & 1.00 & & \\
\hline Ox & & 0.35 & & 0.70 & 0.47 & 0.53 & & & & & & & 0.72 & 0.47 & & 0.69 & & 1.00 & \\
\hline \multirow[t]{2}{*}{$\mathbf{P h}$} & & \begin{tabular}{|l|}
0.37 \\
\end{tabular} & & 0.53 & & & & & & & & & 0.39 & 0.67 & \begin{tabular}{|l|l|}
0.45 \\
\end{tabular} & 0.82 & & 0.57 & 1.00 \\
\hline & $\mathbf{A l}$ & $\mathbf{T i}$ & $\mathbf{K}$ & $\mathbf{R b}$ & $\mathrm{V}$ & $\mathrm{Ni}$ & As & Cd & $\mathbf{P b}$ & $\mathrm{Na}$ & $\mathrm{Cl}$ & NO3 & SO4 & MSA & \begin{tabular}{|l|} 
Ad \\
\end{tabular} & Su & \begin{tabular}{|l|l|} 
Ma \\
\end{tabular} & $\mathbf{O x}$ & $\mathbf{P h}$ \\
\hline \multicolumn{20}{|l|}{$>1 \mu \mathrm{m}$} \\
\hline Al & 1.00 & & & & & & & & & & & & & & & & & & \\
\hline $\mathrm{Ti}$ & 0.56 & 1.00 & & & & & & & & & & & & & & & & & \\
\hline $\mathbf{K}$ & & & 1.00 & & & & & & & & & & & & & & & & \\
\hline $\mathbf{R b}$ & 0.62 & & \begin{tabular}{|l|l|}
0.48 \\
\end{tabular} & 1.00 & & & & & & & & & & & & & & & \\
\hline $\mathbf{V}$ & & 0.40 & & 0.31 & 1.00 & & & & & & & & & & & & & & \\
\hline $\mathbf{N i}$ & & 0.30 & & & & 1.00 & & & & & & & & & & & & & \\
\hline As & & 0.37 & & & 0.33 & & 1.00 & & & & & & & & & & & & \\
\hline $\mathrm{Cd}$ & & & & & 0.66 & 0.41 & \begin{tabular}{|l|}
0.34 \\
\end{tabular} & 1.00 & & & & & & & & & & & \\
\hline $\mathbf{P b}$ & 0.43 & 0.45 & & 0.36 & 0.51 & 0.45 & & \begin{tabular}{l|l}
0.65 \\
\end{tabular} & 1.00 & & & & & & & & & & \\
\hline $\mathrm{Na}$ & 0.49 & 0.42 & & & & & & & & 1.00 & & & & & & & & & \\
\hline $\mathrm{Cl}$ & 0.45 & \begin{tabular}{|l|}
0.48 \\
\end{tabular} & & & & & & & & \begin{tabular}{l|l}
0.90 & 1 \\
\end{tabular} & 1.00 & & & & & & & & \\
\hline NO3 & 0.38 & & & \begin{tabular}{|l|}
0.32 \\
\end{tabular} & 0.41 & & & & & \begin{tabular}{l|l}
0.64 & 0 \\
\end{tabular} & 0.30 & 1.00 & & & & & & & \\
\hline SO4 & 0.39 & & \begin{tabular}{|l|l}
0.81 \\
\end{tabular} & $0.64 \mid$ & & & & & & \begin{tabular}{l|l}
0.37 & 0 \\
\end{tabular} & 0.29 & 0.36 & 1.00 & & & & & & \\
\hline MSA & & & & & & & & & & 0.32 & & & & 1.00 & & & & & \\
\hline Ad & & & & & & & & & & & & & & & 1.00 & & & & \\
\hline Su & 0.39 & & & \begin{tabular}{|l|}
0.28 \\
\end{tabular} & & & & & & 0.30 & & & & & & 1.00 & & & \\
\hline Ma & & & & & & & & & & & & & & & \begin{tabular}{|l|l|}
0.57 & \\
\end{tabular} & & 1.00 & & \\
\hline Ox & 0.59 & \begin{tabular}{|l|}
0.29 \\
\end{tabular} & & \begin{tabular}{|l|}
0.48 \\
\end{tabular} & & & & & & 0.45 & & 0.59 & 0.35 & & & 0.45 & & 1.00 & \\
\hline \multirow[t]{2}{*}{$\mathbf{P h}$} & & 0.29 & & & & & & & & & 0.34 & & & & \begin{tabular}{|l|l|}
0.30 \\
\end{tabular} & & & & 1.00 \\
\hline & Al & $\mathbf{T i}$ & K & $\mathbf{R b}$ & V & $\mathrm{Ni}$ & As & Cd & $\mathbf{P b}$ & $\mathrm{Na}$ & $\mathrm{Cl}$ & $\mathrm{NO3}$ & SO4 & MSA & Ad & Su & Ma & Ox & $\mathbf{P h}$ \\
\hline
\end{tabular}

occur varies between species. These results point to differences in the species with regard to their source, formation mechanism, and eventual fate.

One factor relevant to the mass size distribution plots is the source origin of sampled air masses. The CWT plots in Fig. 12 reveal the bulk of the concentration of a few species (e.g., phthalate, succinate, and MSA) was explained by southwesterly flow. Consistent with the PMF results showing that the biomass burning factor contributed the most to these three species, the predominant fire sources were to the southwest of Luzon. Past work has linked these areas to significant biomass burning influence over Luzon and the South China
Sea during the SWM season (Atwood et al., 2017; Ge et al., 2017; Hilario et al., 2020b; Reid et al., 2016; Song et al., 2018; Wang et al., 2013; Xian et al., 2013). It is noteworthy that the CWT maps for SWM18 reveal more influence from the biomass burning hotspots to the southwest (e.g., Borneo and Sumatra), in contrast to SWM19, pointing to more biomass burning influence in the former season. Oxalate's CWT profile shows the most spatial heterogeneity in terms of source regions; this is consistent with it being an end product in the oxidation of other carboxylic acids that can originate from numerous sources. Finally, adipate and maleate similarly showed a localized hotspot in terms of where their 

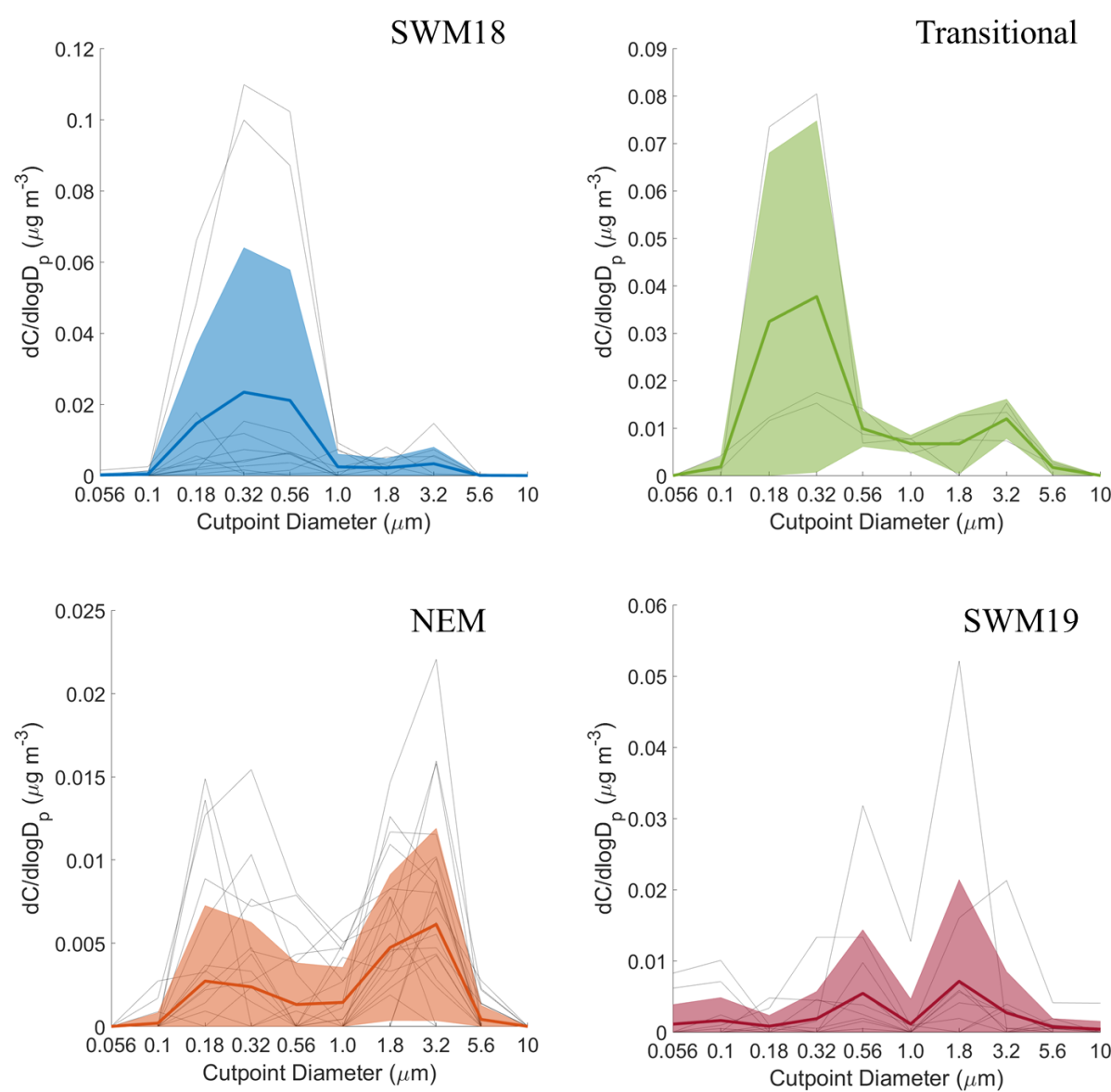

Figure 6. Seasonal size distributions of phthalate. Gray lines represent individual sets, dark colored lines are the average of all seasonal distributions, and transparent colored areas represent 1 standard deviation. Note that the range of concentrations presented on the $y$ axis varies for each season.

greatest influence originated, approximately $290 \mathrm{~km}$ to the north-northwest of MO. This could be partly linked to the Sual coal-fired power station located near that area, where an ash disposal site is also in close proximity. The uniquely similar CWT maps between adipate and maleate are consistent, with them having few correlations, if any, with species aside from each other (Table S6). Subsequent sections discuss each organic acid and MSA in more detail, beginning with larger acids since knowledge of their behavior is important to better understand the smaller acids.

\section{Discussion}

\subsection{Phthalate}

Results from Sect. 4 show that phthalate has the following characteristics:

i. influenced most by biomass burning $(49.5 \%)$, followed by combustion $(27.4 \%)$, crustal sources $(13.3 \%)$, and then sea salt $(9.9 \%)$; ii. significant correlations with more species in Table S6 than any other organic acid or MSA;

iii. comparable mass size distribution modes in the sub- and supermicrometer size ranges;

iv. highest mass concentration in the transitional period but also significantly different concentrations between the two SWM seasons;

v. concentrations dominated by sources to the southwest.

A more detailed examination based on seasonally resolved mass size distributions and CWT maps follows to try to gain more insights into this species. Although not referenced hereafter, Table S7 provides numerical details about mass concentration mode sizes and associated concentrations for each season and the cumulative dataset for each species.

The average size distributions for phthalate appeared bimodal for each individual season (Fig. 6). Depending on the season, concentration peaks occurred in three separate MOUDI stages for the submicrometer range and between $1.8-3.2$ or $3.2-5.6 \mu \mathrm{m}$ in the supermicrometer range. The 

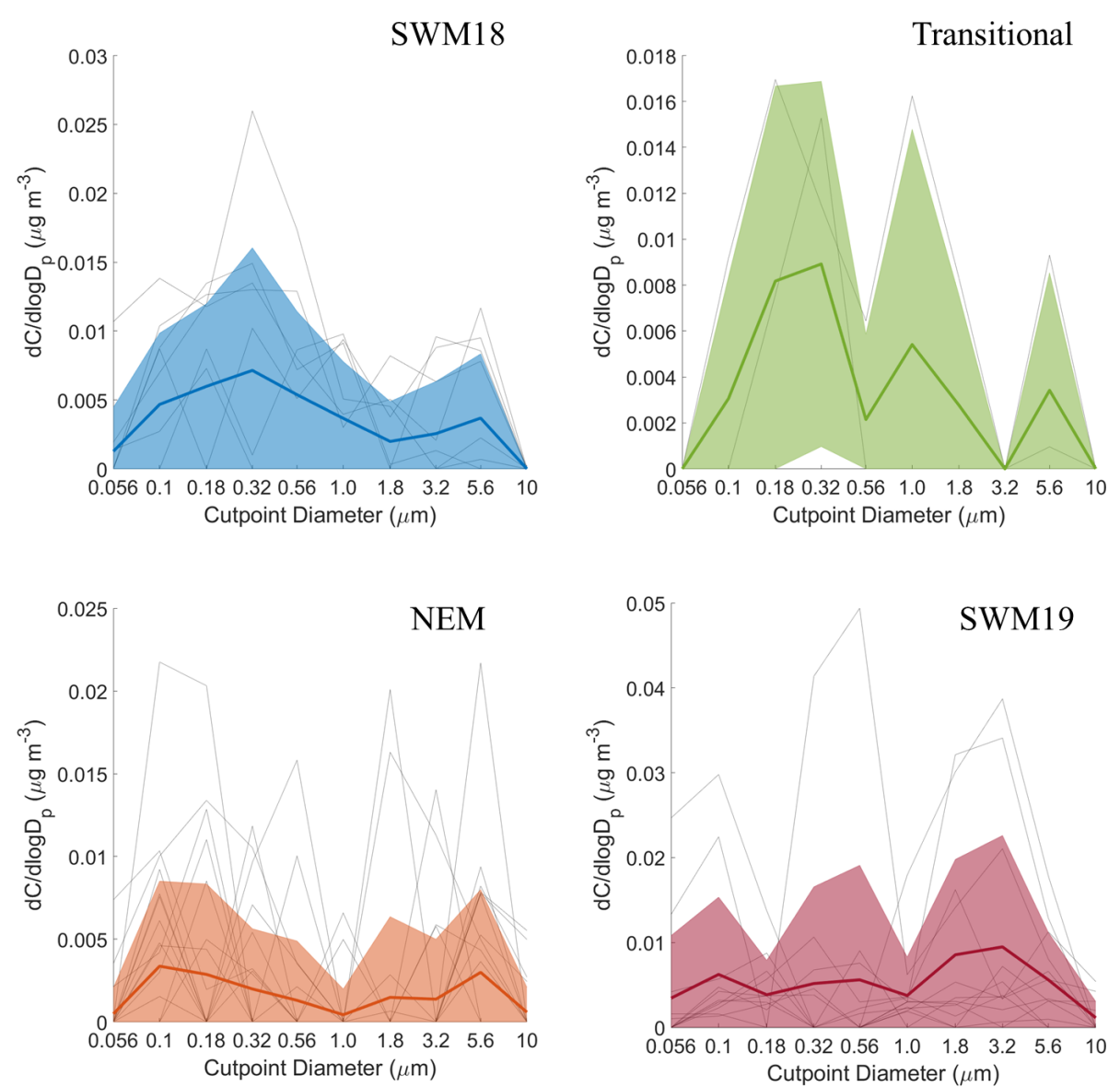

Figure 7. Same as Fig. 6 but for adipate.

NEM season was unique in that the supermicrometer peak was considerably more pronounced than in the submicrometer range, which was a rare occurrence in this study for all species except adipate. Phthalate appears in the submicrometer range due to secondary formation by photo-oxidation (i.e., Kautzman et al., 2010; Kawamura and Ikushima, 2002; Kawamura and Yasui, 2005; Kleindienst et al., 2012) and from primary emissions (i.e., combustion, biomass/waste burning) (i.e., Deshmukh et al., 2016; Kawamura and Kaplan, 1987; Kumar et al., 2015; Kundu et al., 2010). Its general presence in the supermicrometer range, especially during the NEM season, can be explained by possible adsorption onto larger particles such as dust and sea salt (i.e., Wang et al., 2012, 2017). Others have observed an enhancement in phthalate in the supermicrometer mode, specifically in Xi' an, China, due to suspected adsorption of its vapor form (Wang et al., 2012) derived from photo-oxidation of naphthalene (Ho et al., 2006; Wang et al., 2011, 2012, 2017).

CWT results for phthalate (Fig. S3) showed high concentrations across all seasons coming from the southwest, most notably in the SWM18 and SWM19 seasons. The significant reduction in phthalate levels from SWM18 $\left(17 \pm 25 \mathrm{ng} \mathrm{m}^{-3}\right)$ to SWM19 $\left(5.7 \pm 7.4 \mathrm{ng} \mathrm{m}^{-3}\right)$ is coincident with a stronger influence from biomass burning from the southwest in 2018 . Figure 3 showed that the highest concentration of phthalate occurred in the transitional period, assumed to be largely due to local emissions (e.g., vehicular traffic) based on the CWT results, with a significant influence in the immediate vicinity of Luzon unlike the other seasons. The peculiar size distribution results for the NEM season can be explained by the CWT map showing a strong influence from the northeast, which likely includes supermicrometer aerosol influences from sea salt and dust from East Asia. The reduced influence of upwind anthropogenic and biomass burning emissions during the NEM season can explain the lower seasonal concentrations, especially in the submicrometer size range (Hsu et al., 2009).

\subsection{Adipate}

Adipate was shown in Sect. 4 to have the following features:

i. influenced most by crustal sources $(35.9 \%)$, followed by combustion $(32.9 \%)$, biomass burning $(26.4 \%)$, and finally sea salt $(4.7 \%)$;

ii. only correlated with maleate and phthalate; 

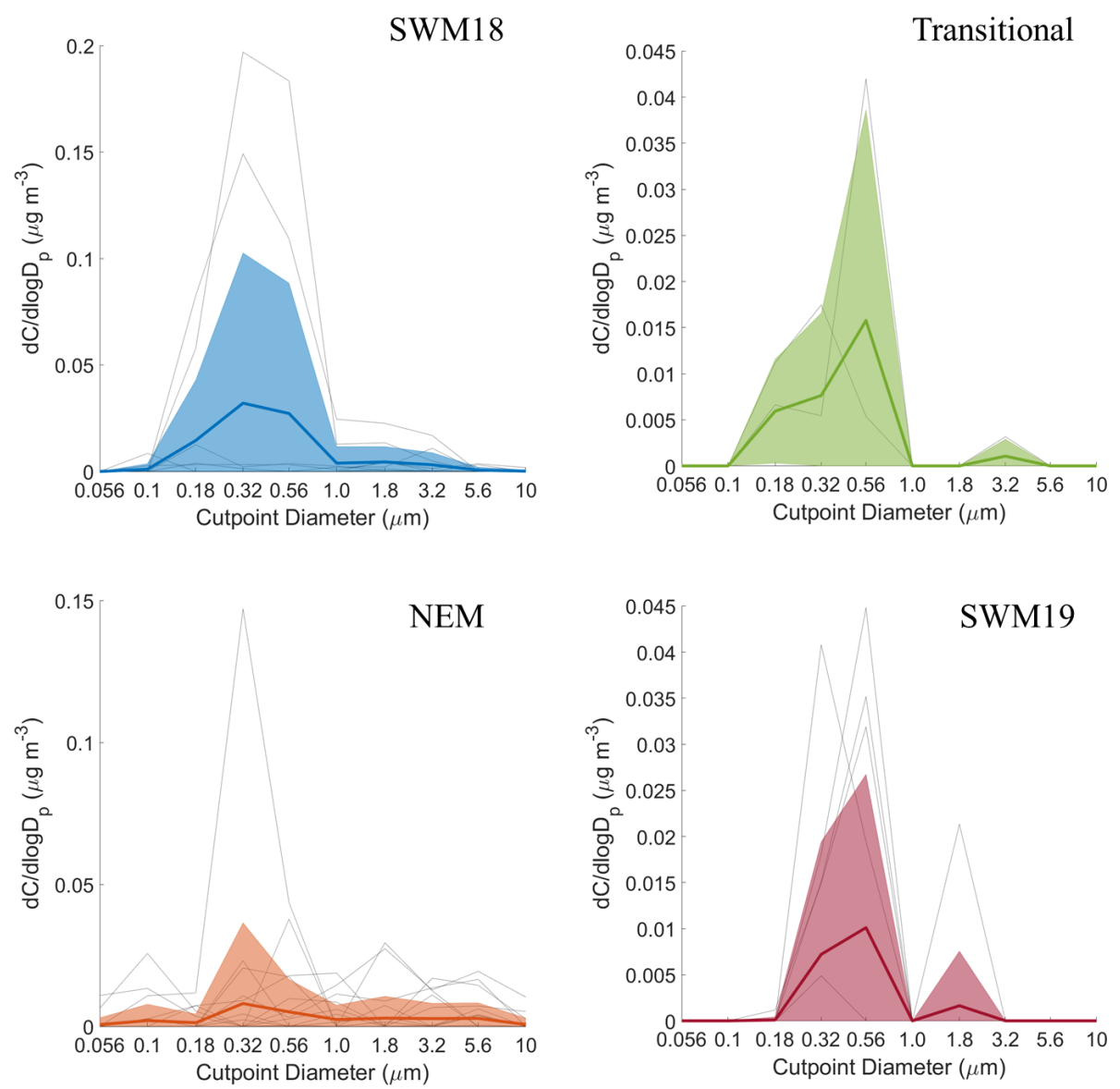

Figure 8. Same as Fig. 6 but for succinate.

iii. comparable concentrations in the sub- and supermicrometer size ranges, with a mode between 5.6 and $10 \mu \mathrm{m}$;

iv. highest mass concentration in the SWM seasons but especially the SWM19 season;

v. concentrations dominated by sources from the southwest as well as from the northwest.

Mass size distributions for adipate were the most variable in structure compared to the other five species, with multiple peaks present at different sizes (Fig. S2). In general, its distributions appeared uniquely and consistently trimodal, with the exception of the SWM18 season when the distribution was bimodal (Fig. 7). Modes appeared between 0.10-0.18 and $0.32-0.56 \mu \mathrm{m}$ for the submicrometer range and between $1.0-1.8$ and 3.2-5.6 $\mu \mathrm{m}$ for the supermicrometer range. The SWM19 season was unique for adipate as the highest peak was in the supermicrometer range, and it was higher than any other peak across the other seasons. Submicrometer adipate is likely derived from photo-oxidation of higher chain organic acids (i.e., van Drooge and Grimalt, 2015), ozonolysis of vehicular emissions (i.e., Grosjean et al., 1978), and the primary emissions of biomass burning (i.e., Graham et al., 2002). The appearance in the supermicrometer range is likely due to adsorption onto larger particles such as dust and sea salt (e.g., Wang et al., 2012, 2017). As the PMF results suggest crustal sources were more influential for adipate in contrast to sea salt, dust was more likely the supermicrometer particle type that adipate preferentially partitioned to. The source of the dust was likely a combination of long-range transport from (i) the southwest, especially during biomass burning periods, (ii) East Asia, and (iii) locally generated dust via anthropogenic activities (Fig. S4).

Past work in the study region showed that broad mass size distributions with comparable concentrations in the sub- and supermicrometer ranges were coincident with wet scavenging (Braun et al., 2020) and appreciable primary emissions of sea salt and dust (AzadiAghdam et al., 2019; Cruz et al., 2019). Scavenging was suggested to remove transported pollution while allowing for more pronounced contributions from more localized emissions, which could include vehicular traffic, sea salt, and anthropogenic forms of dust (e.g., road dust, construction), all of which are consistent with adipate's mass size distribution data and CWT maps (Fig. S4) 

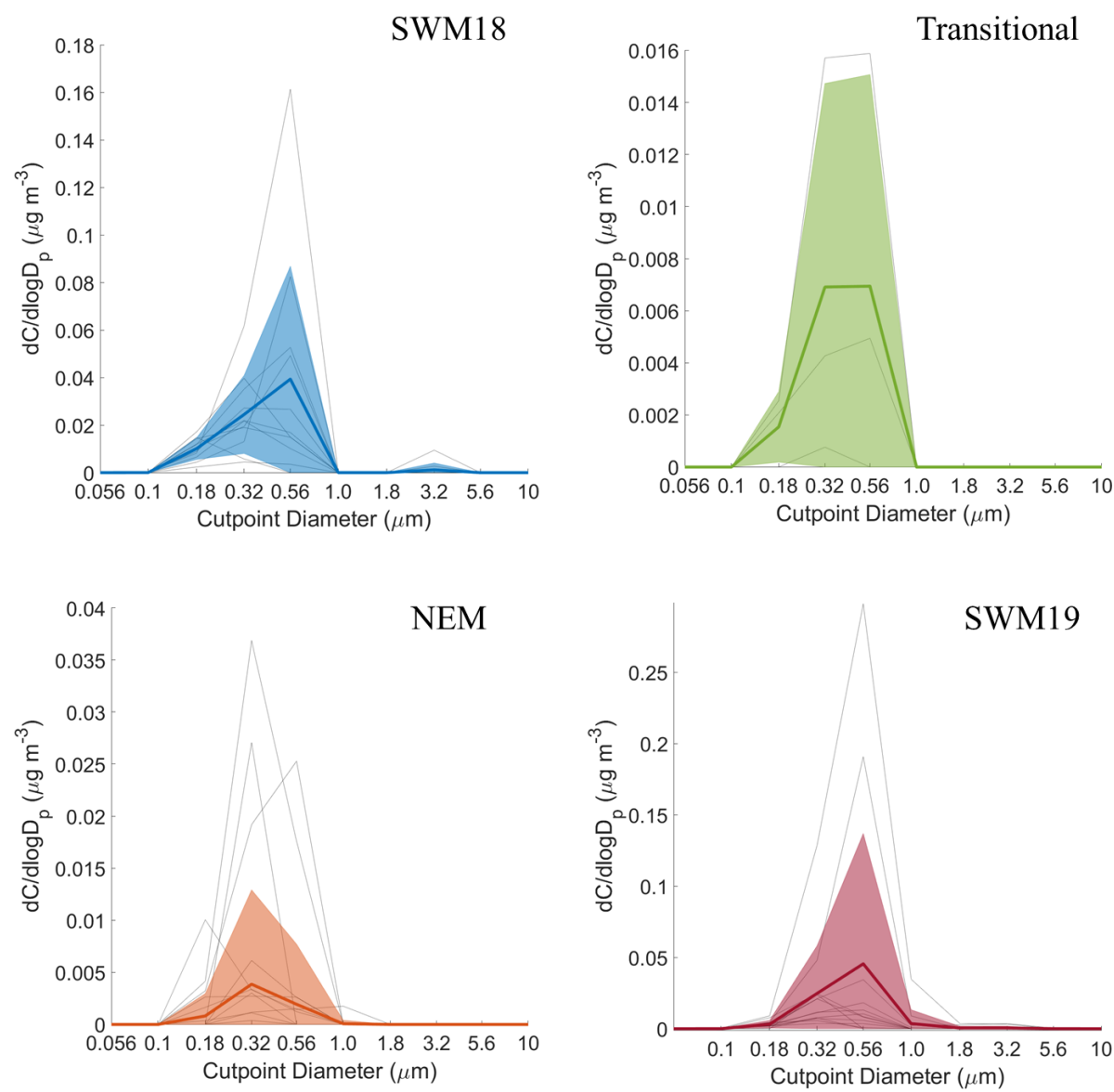

Figure 9. Same as Fig. 6 but for maleate.

showing high concentrations predominately around Luzon for all seasons.

\subsection{Succinate}

Succinate exhibited the following characteristics:

i. influenced primarily by biomass burning $(90.3 \%)$, followed by crustal sources $(9.7 \%)$;

ii. high correlation coefficients $(0.67-0.76)$ with oxalate, phthalate, and MSA (Table S6);

iii. mass focused in the submicrometer range;

iv. highest mass concentrations in the SWM18 season, and, similar to phthalate, a significant reduction in the SWM19 season;

v. concentrations dominated by sources from the southwest.

The average size distributions for succinate varied in the number of peaks present (2-4) but on average were bimodal with a submicrometer mode usually between 0.32 0.56 or $0.56-1.0 \mu \mathrm{m}$ and a smaller supermicrometer mode

between either $1.8-3.2$ or $3.2-5.6 \mu \mathrm{m}$ (Fig. 8). The chief source of succinate, which is concentrated in the submicrometer peak, is biomass burning (Pratt et al., 2011; Vasconcellos et al., 2010), which is reinforced by the PMF results (Table 2), its high correlation with the biomass burning tracer $\mathrm{Rb}(r=0.67$; Table S6) (Braun et al., 2020), and CWT maps showing its most pronounced influence from biomass burning hotspots to the southwest during the SWM18 season (Fig. S5). There likely was also local biomass burning during the NEM season contributing to succinate concentrations. Hilario et al. (2020a) showed based on satellite data that local fire activity peaks between March and May. There was less influence from biomass burning in the SWM19 season, which is why succinate's levels were lower $\left(4.7 \pm 7.4 \mathrm{ng} \mathrm{m}^{-3}\right)$ than in the SWM18 season $\left(22 \pm 43 \mathrm{ng} \mathrm{m}^{-3}\right)$. Similar to phthalate and adipate, there were more local hotspots of concentration in seasonal CWT maps, pointing to local anthropogenic sources such as vehicular traffic and the presence of supermicrometer particles like dust and sea salt that succinate can partition to (e.g., Wang et al., 2012, 2017). 

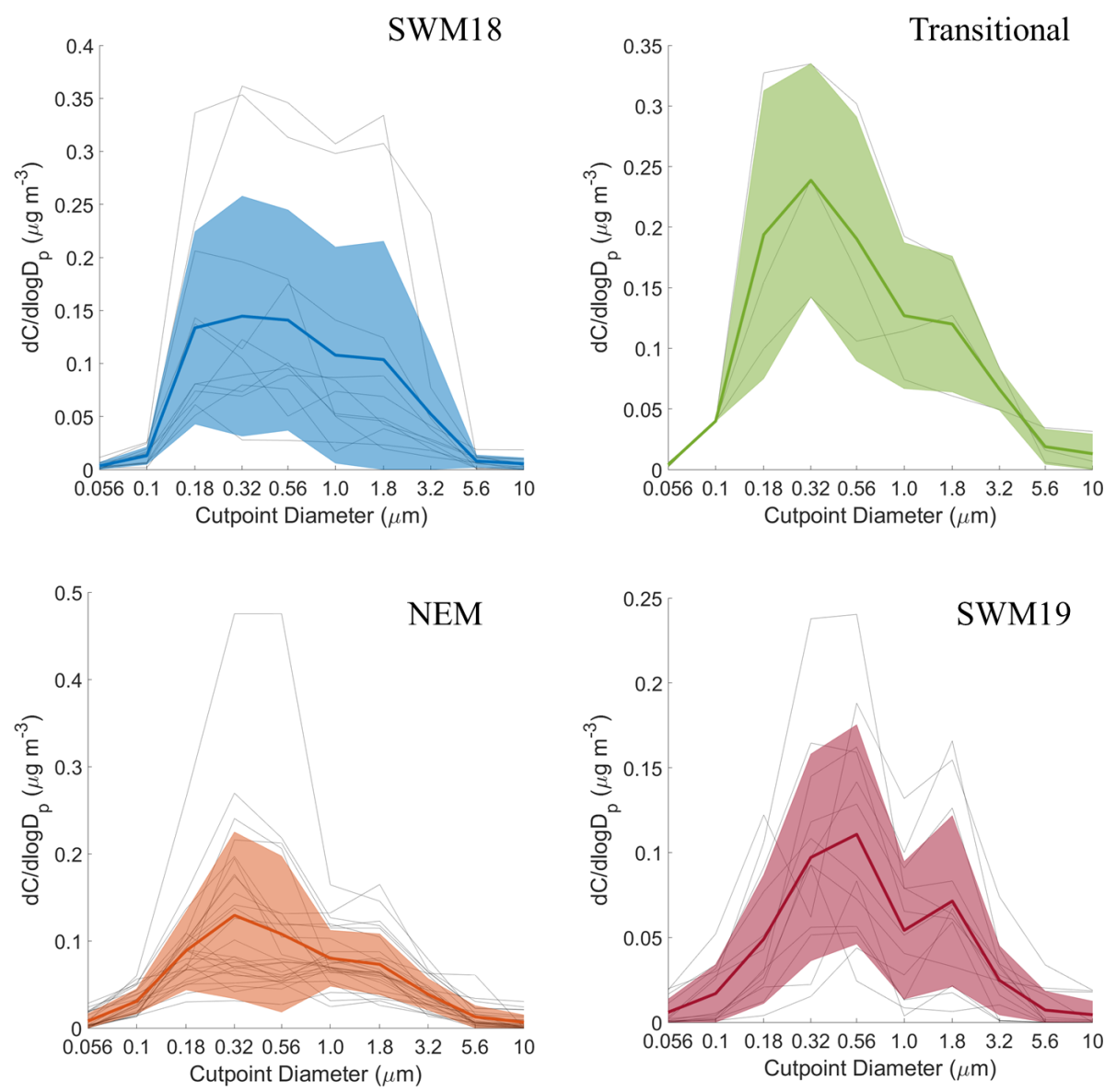

Figure 10. Same as Fig. 6 but for oxalate.

\subsection{Maleate}

The results of Sect. 4 showed that maleate had the following attributes:

i. influenced most by combustion (69.7\%), followed by waste processing $(30.1 \%)$, and then barely by crustal sources $(0.2 \%)$;

ii. only correlated with adipate of all species shown in Table S6;

iii. a unimodal mass size distribution, with negligible contribution in the supermicrometer range;

iv. highest mass concentration in the SWM19 season but comparable to the SWM18 season;

v. the most localized sources as compared to the other species examined, as shown by CWT maps (Fig. 11).

The average seasonal size distributions for maleate appeared to be unimodal, with peaks between $0.32-0.56$ and 0.56 $1.0 \mu \mathrm{m}$ (Fig. 9). The absence of a supermicrometer peak, in contrast to most other species, suggests that it had less diverse sources and was derived from combustion emissions

without being adsorbed onto supermicrometer particles like the other species investigated. The association of maleate with the waste processing source factor in Table 2 can be explained partly by the burning and recycling of electronic waste (Cruz et al., 2019; Gullett et al., 2007; Iijima et al., 2007). The Pabroa et al. (2011) study reported that there are few licensed operators for battery recycling, but there are numerous unregulated melters frequently melting metal and discarding the waste.

Seasonal CWT maps for maleate (Fig. S6) consistently showed hotspots around Luzon, indicative of local emissions. Maleate concentrations for the SWM18 $\left(19 \pm 15 \mathrm{ng} \mathrm{m}^{-3}\right)$ and SWM19 $\left(19 \pm 34 \mathrm{ng} \mathrm{m}^{-3}\right)$ were significantly higher than the other seasons (transitional: $3.8 \pm 4.2 \mathrm{ng} \mathrm{m}^{-3}$; NEM: $1.7 \pm 3.7 \mathrm{ng} \mathrm{m}^{-3}$ ), and this could likely be due to increased traffic emissions because of gridlock due to intense rainfall. It should be noted that the Ateneo de Manila campus has student break periods in March, April, May, and December (Hilario et al., 2020a); those months pertain to the NEM season, which could lead to lower combustion emissions from vehicles (e.g., maleate and phthalate). Although the SWM season is associated with enhanced precipitation over Metro Manila, lower boundary layer height and appreciable RH val- 

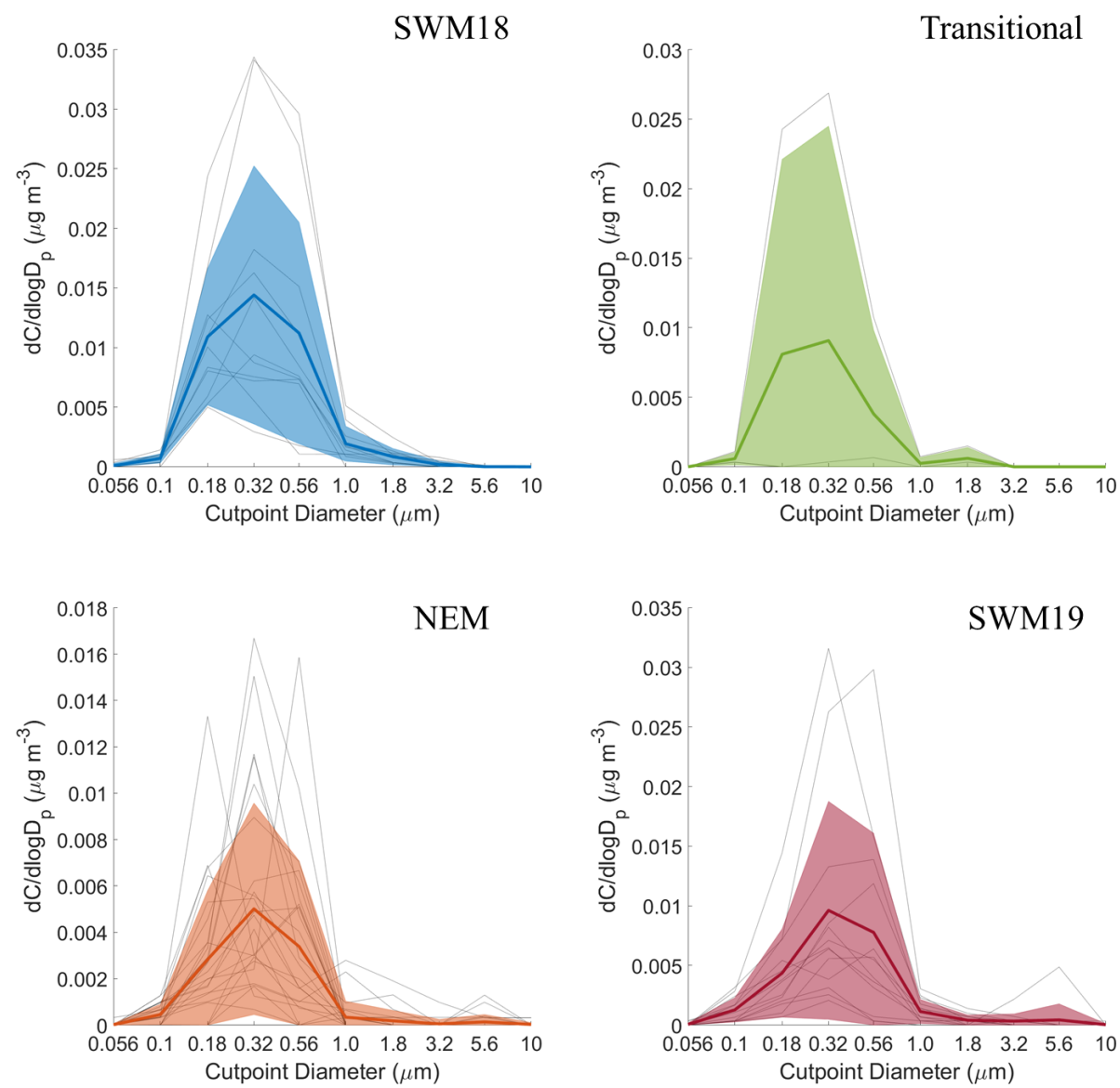

Figure 11. Same as Fig. 6 but for MSA.

ues could counteract wet scavenging to some degree by promoting aqueous processing of aerosol (Hilario et al., 2020a). Furthermore, maleate's largely submicrometer size distribution (Fig. 9) may reduce the efficiency of wet scavenging (Greenfield, 1957).

\subsection{Oxalate}

Oxalate was shown to have the following traits:

i. influenced somewhat uniformly by combustion $(32.9 \%)$ and crustal $(31.2 \%)$ sources, followed by biomass burning $(25.4 \%)$, and waste processing $(10.5 \%)$;

ii. only organic acid to correlate with combustion tracers $(\mathrm{V}, \mathrm{Ni})$;

iii. pronounced presence in both the sub- and supermicrometer size ranges;

iv. highest mass concentrations in the transitional period;

v. contributions from the southwest, east/northeast, and local sources.
Oxalate concentrations in this study (37.67-472.82 $\mathrm{ng} \mathrm{m}^{-3}$ ) were surprisingly low for such a polluted megacity with strong regional sources. For context, concentrations in a few other regions are as follows: $270-1350 \mathrm{ng} \mathrm{m}^{-3}$ in Tokyo, Japan (Kawamura and Ikushima, 2002; Sempére and Kawamura, 1994); 195-669 $\mathrm{ng} \mathrm{m}^{-3}$ in Beijing, China (Du et al., 2014); and $149-735 \mathrm{ng} \mathrm{m}^{-3}$ in Thumba, India (Hegde et al., 2016).

The average size distributions for oxalate appeared bimodal for each individual season with modes between 0.32 0.56 and $0.56-1.0 \mu \mathrm{m}$ for the submicrometer range and a separate mode between $1.8-3.2 \mu \mathrm{m}$ for the supermicrometer range (Fig. 10). A unique aspect for oxalate was its consistency in having a bimodal profile each season, with the supermicrometer mode always between 1.8-3.2 $\mu \mathrm{m}$. Note that the modes discussed here represent the most pronounced ones, but others could have been present too, reflecting other sources. Submicrometer oxalate likely originated from secondary production from both biogenic and anthropogenic precursor emissions and potentially from primary emissions (i.e., combustion/biomass burning) (i.e., Decesari et al., 2006; Falkovich et al., 2005; Golly et al., 2019; Kundu et al., 2010; Wang et al., 2010). Of all the six species studied, ox- 
(a) Phthalate

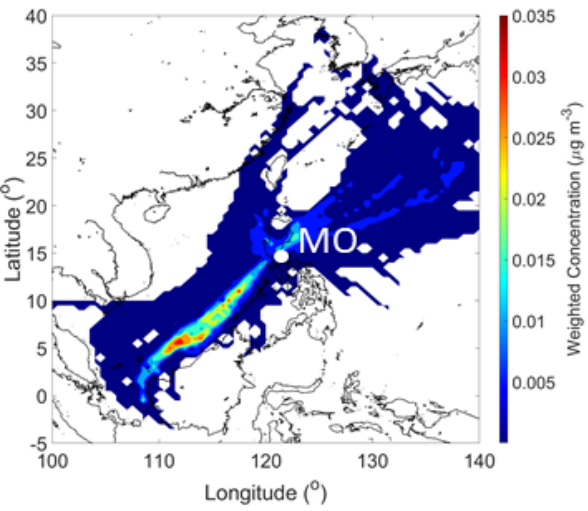

(c) Succinate

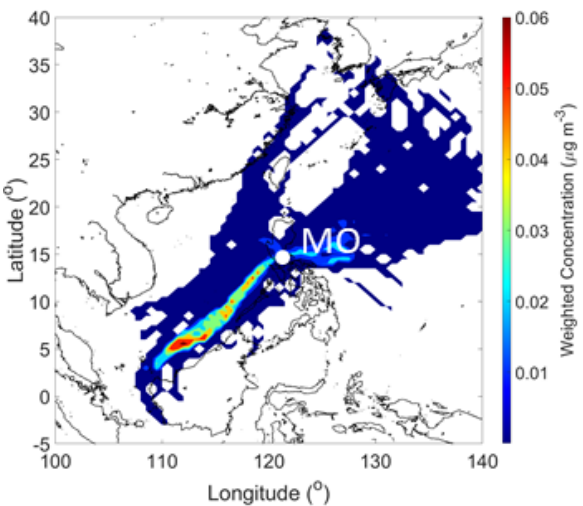

(e) Oxalate

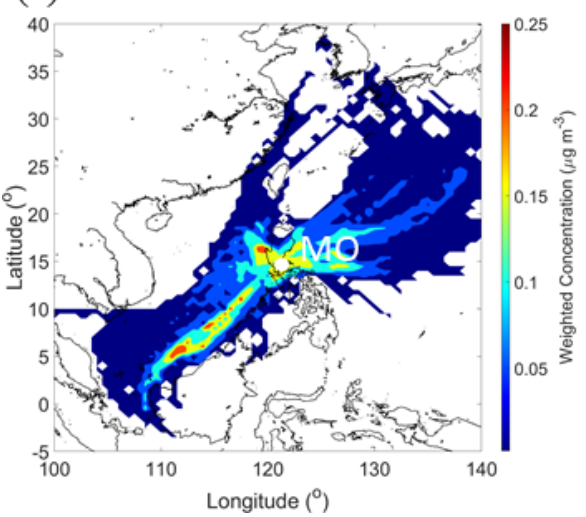

(b) Adipate

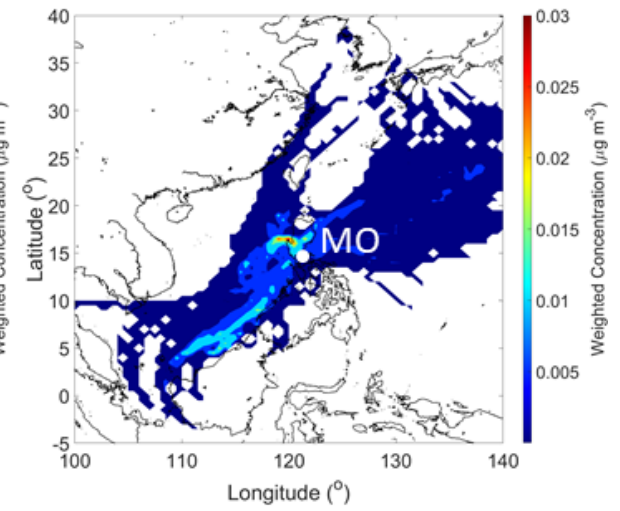

(d) Maleate

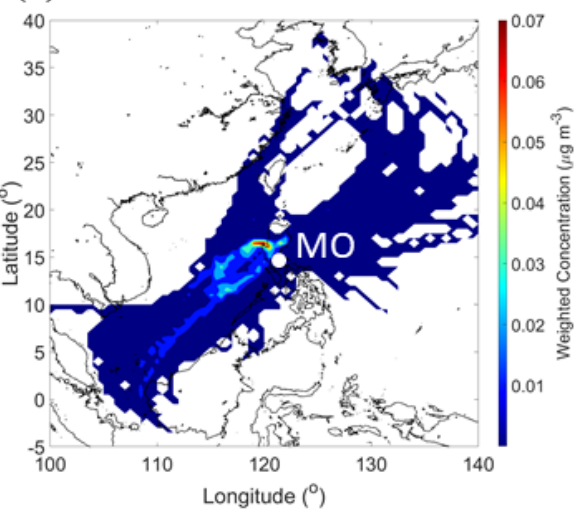

(f) MSA

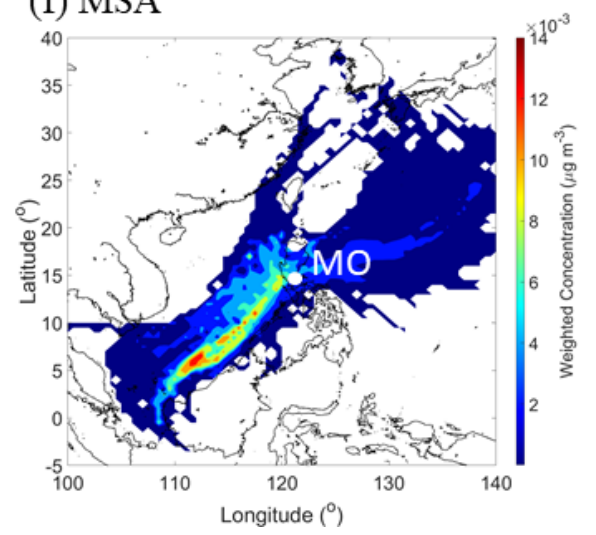

Figure 12. CWT maps of (a-e) individual organic acids and (f) MSA over the entire sampling period. These results are based on all MOUDI sizes $(0.056-18 \mu \mathrm{m})$. Maps showing the seasonal results for each organic acid and MSA are shown in the Supplement (Figs. S3-S8).

alate was best correlated with $\mathrm{SO}_{4}^{2-}(r=0.69$; Table S6), especially in the submicrometer range $(r=0.72$; Table 3$)$, which is consistent with their common production mechanism via aqueous processing (Sorooshian et al., 2006; Yu et al., 2005). Additionally, high concentrations of oxalate in the transitional period suggest that photo-oxidation was an important process for oxalate formation since the transitional period had low rain and high solar radiation. The prominent supermicrometer presence was likely due to adsorption onto supermicrometer particles. Past work by Sullivan and Prather (2007) reported the following with regard to oxalate's behavior in coarse particles of relevance to this study: (i) oxalic acid was predominately associated with mineral dust and to a lesser degree with aged sea salt; (ii) even though most of the total mass was sea salt, there was more oxalate per mass of mineral dust than sea salt; (iii) Asian dust particles are more alkaline as opposed to sea salt and therefore act as better sinks for dicarboxylic acids than sea salt; and (iv) it is feasi- 
ble that a large fraction of supermicrometer dicarboxylic acid mass in remote marine air is associated with mineral dust and not sea salt. The PMF results from the present study suggest that oxalate was much more influenced by crustal sources $(31.2 \%)$ versus sea salt $(0 \%)$, similar to phthalate, adipate, and succinate (Table 2). Reinforcing the relationship between oxalate and dust is the significant correlation between oxalate and both $\mathrm{Al}(r=0.59)$ and $\mathrm{Ti}(0.29)$ in the supermicrometer range.

CWT results for oxalate (Fig. S7) showed high concentrations around Luzon for all seasons, with the caveat that the SWM18 exhibited high concentrations coming from the southwest, which has already been linked to biomass burning emissions. The difference in oxalate levels between the SWM18 $\left(178 \pm 139 \mathrm{ng} \mathrm{m}^{-3}\right)$ and SWM19 $\left(110 \pm 62 \mathrm{ng} \mathrm{m}^{-3}\right)$ seasons is largely due to the enhanced contribution of biomass burning in the former season since oxalate is abundant in fire emissions (Falkovich et al., 2005; Mardi et al., 2018; Narukawa et al., 1999).

\subsection{MSA}

Previous sections revealed the following characteristics for MSA:

i. influenced most by combustion $(57.4 \%)$, followed by biomass burning $(41.2 \%)$, waste processing $(1.4 \%)$, and then crustal sources $(0.1 \%)$;

ii. significantly correlated with succinate, oxalate, phthalate, and $\mathrm{SO}_{4}^{2-}$;

iii. similar to maleate, primarily consisted of a submicrometer mass size distribution peak with only minor contributions from the supermicrometer mode;

iv. concentration highest during the SWM18 season;

v. concentrations dominated by sources from the southwest.

Concentrations of MSA in this study were surprisingly low for a site so close to marine and anthropogenic sources (0.10$23.23 \mathrm{ng} \mathrm{m}^{-3}$ ). For context, MSA concentrations in nearby regions are as follows: $30-60 \mathrm{ng} \mathrm{m}^{-3}$ in Nanjing, China (Yang et al., 2005), and 29-66 $\mathrm{ng} \mathrm{m}^{-3}$ over the China Sea (Gao et al., 1996).

The average size distributions for MSA appeared unimodal, with the peak size being between $0.32-0.56 \mu \mathrm{m}$ (Fig. 11). The consistent mass size distribution for MSA in all seasons, similar to maleate, could be due to some combination of limited sources and production pathways. Surprisingly, MSA showed no association with the sea salt source factor (Table 2), even though it would be expected given that DMS is co-emitted from the ocean with sea salt. Due to the proximity of the sampling site to the ocean, it is possible that the local sea salt was relatively fresh with short transport time, which could potentially explain the lack of an association with MSA as it requires time to be produced from its marine precursor DMS. Instead, combustion and biomass burning sources were more significantly related to MSA, which is consistent with some past studies linking MSA to anthropogenic sources (Yuan et al., 2004) and biomass burning (Sorooshian et al., 2015). Consequently, concentrations of MSA from these other non-marine sources could be much higher, causing the PMF model to associate MSA with non-sea-salt-related sources. CWT results for MSA (Fig. S8) showed high concentrations coming from the southwest during the SWM18 and SWM19 seasons and from the eastnortheast during the NEM and transitional period.

Both MSA and oxalate had significantly lower concentrations than other regions, and there are a few possible explanations for this. First, it is worth noting that degradation of these species is unlikely due to storage or sonication as careful procedures were followed, as noted in Sect. 2.2. The Philippines has relatively high temperatures, humidity, and solar radiation year round, providing optimal conditions for processing and degradation to occur, yielding low concentrations of MSA and oxalate. Furthermore, there are mechanisms by which species such as oxalate can be degraded via complexation effects with metal cations (Paris and Desboeufs, 2013; Siffert and Sulzberger, 1991; Sorooshian et al., 2013; Zuo, 1995), which are abundant in the study region.

\section{Conclusions}

This work used a 16-month long dataset of size-resolved aerosol composition to investigate the nature of five organic acids (oxalate, succinate, adipate, maleate, and phthalate) and MSA in the polluted Metro Manila region in the Philippines. Selected results are as follows in order of the three major questions posed at the end of Sect. 1.

- Organic acids and MSA contribute only a small fraction to the total gravimetric aerosol mass in Metro Manila $(0.80 \pm 0.66 \%)$. The combined contribution of these six species was similar between the sub- and supermicrometer range $(0.78 \%$ and $0.84 \%$, respectively). After accounting for water-soluble ions and elements, and black carbon, there still was an unresolved mass fraction amounting to $33.74 \%$ across all sizes and $17.78 \%$ and $69.10 \%$ for sub- and supermicrometer sizes, respectively. Therefore, future work is still warranted to identify what the missing fraction is comprised of, which is speculated to be water-insoluble organics and elements.

- Oxalate was the most abundant of the six species, accounting for $69.1 \%-87.3 \%$ of the total combined mass of the six species depending on the season. However, the bulk concentrations of oxalate were unusually low $\left(149 \pm 94 \mathrm{ng} \mathrm{m}^{-3}\right)$ for such a polluted area in contrast to 
other populated regions. Concentrations of the other five species were much lower than oxalate, with mean levels for the entire study period being less than $10 \mathrm{ng} \mathrm{m}^{-3}$. In particular, MSA exhibited the lowest mean concentration $\left(5.4 \pm 5.2 \mathrm{ng} \mathrm{m}^{-3}\right)$. It is unclear exactly as to the reason for the low concentrations of the examined species in light of the diverse marine and anthropogenic sources in the region. The role of wet scavenging, especially in the SWM seasons, will be the subject of future research.

- The six species exhibited different behavior seasonally, both in terms of relative concentration and mass size distribution. The SWM18 season was uniquely different than the SWM19 season, owing to more biomass burning emissions transported from the southwest that yielded enhanced levels for most species in the submicrometer range, especially succinate, MSA, oxalate, and phthalate. Enhanced precipitation in the SWM seasons also was coincident with more influence from localized emissions, leading to enhanced levels in the sub- and supermicrometer ranges depending on the species. The NEM season was characterized by generally lower concentrations of most species as air was predominantly transported from the northeast, with reduced influence of anthropogenic and biomass burning emissions. Phthalate was enhanced in the supermicrometer range during the NEM season due to presumed adsorption to Asian dust and to a lesser extent sea salt. The transitional season was characterized as having a strong influence from localized emissions for all six species, which promoted especially high concentrations of phthalate and oxalate in both the sub- and supermicrometer ranges.

- All species exhibited a prominent submicrometer peak that likely stemmed largely from secondary formation from both anthropogenic and biogenic precursor emissions and was especially prominent during the SWM18 season due to extensive biomass burning influence. Biomass burning was an especially important source for succinate, phthalate, MSA, oxalate, and adipate. All six species exhibited relatively low association with sea salt particles; this was particularly interesting for MSA, which was instead better related to combustion and biomass burning emissions. In contrast to sea salt, most species were linked to crustal emissions, as evident from peaks in the coarse mode during periods of dust influence. Oxalate, adipate, phthalate, and succinate in particular preferentially partitioned to dust rather than sea salt, potentially due to their affinity for alkaline particle types. Oxalate was best correlated with sulfate, especially in the submicrometer mode, explained by their common production via aqueous processing, which is common in the study region, owing to high humidity levels year round.
The results of this study point to the importance of sizeresolved measurements of organic and sulfonic acids as this extensive dataset revealed important changes in mass size distributions between species and for different seasons. The data point to the partitioning of these species to coarse aerosol types and the potentially significant impact of precipitation on either the removal or enhancement of species' mass size distribution modes; these topics warrant additional research to establish more clearly the sensitivity of these species to source regions, transport pathways, and wet scavenging effects. More research is warranted to investigate the remaining fraction of the unresolved mass (approximately one-third of the gravimetric mass) that is not accounted for by black carbon and the water-soluble constituents speciated in this work. This is especially important for the supermicrometer range. Lastly, the current results point to the question as to what drives the affinity of individual species towards the coarse mode for different aerosol types (e.g., dust, sea salt) and how common this is for other regions.

Data availability. Size-resolved aerosol data collected at Manila Observatory are described in Stahl et al. (2020a) (https://www.nature.com/articles/s41597-020-0466-y, last access: 1 July 2020) and archived on figshare (Stahl et al., 2020b) (https://figshare.com/articles/An_Annual_Time_ Series_of_Weekly_Size-Resolved_Aerosol_Properties_in_the_ Megacity_of_Metro_Manila_Philippines/11861859, last access: 1 July 2020) as well as in the NASA data repository at https://asdc.larc.nasa.gov/project/CAMP2Ex, last access: 1 July 2020.

Supplement. The supplement related to this article is available online at: https://doi.org/10.5194/acp-20-15907-2020-supplement.

Author contributions. MTC, MOC, JBS, RAB, ABM, CS, and AS designed the experiment. All coauthors carried out various aspects of the data collection. MTC, RAB, CS, and AS conducted analysis and interpretation of the data. CS and AS prepared the manuscript with contributions from the coauthors.

Competing interests. The authors declare that they have no conflict of interest.

Acknowledgements. The authors acknowledge support from NASA grant 80 NSSC18K0148 in support of the NASA CAMP ${ }^{2}$ Ex project. Rachel A. Braun acknowledges support from the ARCS Foundation. Melliza Templonuevo Cruz acknowledges support from the Philippine Department of Science and Technology's ASTHRD Program. Alexander B. MacDonald acknowledges support from the Mexican National Council for Science and Technology (CONACYT). We acknowledge Agilent Technologies for their support and Shane Snyder's laboratories for ICP-QQQ data. 
Financial support. This research has been supported by the National Aeronautics and Space Administration (NASA) (grant no. 80NSSC18K0148).

Review statement. This paper was edited by Eleanor Browne and reviewed by two anonymous referees.

\section{References}

Adam, M. G., Chiang, A. W. J., and Balasubramanian, R.: Insights into characteristics of light absorbing carbonaceous aerosols over an urban location in Southeast Asia, Environ. Pollut., 257, 113425, https://doi.org/10.1016/j.envpol.2019.113425, 2020.

Agarwal, R., Shukla, K., Kumar, S., Aggarwal, S. G., and Kawamura, K.: Chemical composition of waste burning organic aerosols at landfill and urban sites in Delhi, Atmos Pollut Res, 11, 554-565, https://doi.org/10.1016/j.apr.2019.12.004, 2020.

Akasaka, I., Morishima, W., and Mikami, T.: Seasonal march and its spatial difference of rainfall in the Philippines, Int. J. Climatol., 27, 715-725, https://doi.org/10.1002/joc.1428, 2007.

Alas, H. D., Müller, T., Birmili, W., Kecorius, S., Cambaliza, M. O., Simpas, J. B. B., Cayetano, M., Weinhold, K., Vallar, E., Galvez, M. C., and Wiedensohler, A.: Spatial Characterization of Black Carbon Mass Concentration in the Atmosphere of a Southeast Asian Megacity: An Air Quality Case Study for Metro Manila, Philippines, Aerosol. Air. Qual. Res., 18, 2301-2317, https://doi.org/10.4209/aaqr.2017.08.0281, 2018.

Allen, A. G., Nemitz, E., Shi, J. P., Harrison, R. M., and Greenwood, J. C.: Size distributions of trace metals in atmospheric aerosols in the United Kingdom, Atmos. Environ., 35, 45814591, https://doi.org/10.1016/s1352-2310(01)00190-x, 2001.

Allen, H. C., Laux, J. M., Vogt, R., Finlayson-Pitts, B. J., and Hemminger, J. C.: Water-Induced Reorganization of Ultrathin Nitrate Films on $\mathrm{NaCl}$ : Implications for the Tropospheric Chemistry of Sea Salt Particles, J. Phys. Chem., 100, 6371-6375, https://doi.org/10.1021/jp953675a, 1996.

Andreae, M. O.: Soot carbon and excess fine potassium: long-range transport of combustion-derived aerosols, Science, 220, 11481151, https://doi.org/10.1126/science.220.4602.1148, 1983.

Andreae, M. O. and Crutzen, P. J.: Atmospheric Aerosols: Biogeochemical Sources and Role in Atmospheric Chemistry, Science, 276, 1052-1058, https://doi.org/10.1126/science.276.5315.1052, 1997.

Artaxo, P., Gerab, F., Yamasoe, M. A., and Martins, J. V.: Fine mode aerosol composition at three long-term atmospheric monitoring sites in the Amazon Basin, J. Geophys. Res., 99, 22857-22868, https://doi.org/10.1029/94jd01023, 1994.

Asmi, E., Frey, A., Virkkula, A., Ehn, M., Manninen, H. E., Timonen, H., Tolonen-Kivimäki, O., Aurela, M., Hillamo, R., and Kulmala, M.: Hygroscopicity and chemical composition of Antarctic sub-micrometre aerosol particles and observations of new particle formation, Atmos. Chem. Phys., 10, 4253-4271, https://doi.org/10.5194/acp-10-4253-2010, 2010.

Atwood, S. A., Reid, J. S., Kreidenweis, S. M., Blake, D. R., Jonsson, H. H., Lagrosas, N. D., Xian, P., Reid, E. A., Sessions, W. R., and Simpas, J. B.: Size-resolved aerosol and cloud condensation nuclei $(\mathrm{CCN})$ properties in the remote marine South
China Sea - Part 1: Observations and source classification, Atmos. Chem. Phys., 17, 1105-1123, https://doi.org/10.5194/acp17-1105-2017, 2017.

AzadiAghdam, M., Braun, R. A., Edwards, E.-L., Bañaga, P. A., Cruz, M. T., Betito, G., Cambaliza, M. O., Dadashazar, H., Lorenzo, G. R., Ma, L., MacDonald, A. B., Nguyen, P., Simpas, J. B., Stahl, C., and Sorooshian, A.: On the nature of sea salt aerosol at a coastal megacity: Insights from Manila, Philippines in Southeast Asia, Atmos. Environ., 216, 116922, https://doi.org/10.1016/j.atmosenv.2019.116922, 2019.

Baboukas, E. D., Kanakidou, M., and Mihalopoulos, N.: Carboxylic acids in gas and particulate phase above the Atlantic Ocean, J. Geophys. Res.-Atmos., 105, 14459-14471, https://doi.org/10.1029/1999jd900977, 2000.

Bagtasa, G., Cayetano, M. G., and Yuan, C.-S.: Seasonal variation and chemical characterization of $\mathrm{PM}_{2.5}$ in northwestern Philippines, Atmos. Chem. Phys., 18, 4965-4980, https://doi.org/10.5194/acp-18-4965-2018, 2018.

Bagtasa, G., Cayetano, M. G., Yuan, C.-S., Uchino, O., Sakai, T., Izumi, T., Morino, I., Nagai, T., Macatangay, R. C., and Velazco, V. A.: Long-range transport of aerosols from East and Southeast Asia to northern Philippines and its direct radiative forcing effect, Atmos. Environ., 218, 117007, https://doi.org/10.1016/j.atmosenv.2019.117007, 2019.

Bagtasa, G., and Yuan, C.-S.: Influence of local meteorology on the chemical characteristics of fine particulates in Metropolitan Manila in the Philippines, Atmos. Pollut. Res., 11, 1359-1369, https://doi.org/10.1016/j.apr.2020.05.013, 2020.

Bañares, E. N., Narisma, G. T. T., Simpas, J. B. B., Cruz, F. A. T., Lorenzo, G. R. H., Cambaliza, M. O., and Coronel, R. C.: Diurnal characterization of localized convective rain events in urban Metro Manila, Philippines, AGUFM, 2018, A11J-2367, 2018.

Barbaro, E., Padoan, S., Kirchgeorg, T., Zangrando, R., Toscano, G., Barbante, C., and Gambaro, A.: Particle size distribution of inorganic and organic ions in coastal and inland Antarctic aerosol, Environ. Sci. Pollut. Res. Int., 24, 2724-2733, https://doi.org/10.1007/s11356-016-8042-x, 2017.

Bardouki, H., Berresheim, H., Vrekoussis, M., Sciare, J., Kouvarakis, G., Oikonomou, K., Schneider, J., and Mihalopoulos, N.: Gaseous (DMS, MSA, $\mathrm{SO}_{2}, \mathrm{H}_{2} \mathrm{SO}_{4}$ and DMSO) and particulate (sulfate and methanesulfonate) sulfur species over the northeastern coast of Crete, Atmos. Chem. Phys., 3, 1871-1886, https://doi.org/10.5194/acp-3-1871-2003, 2003a.

Bardouki, H., Liakakou, H., Economou, C., Sciare, J., Smolìk, J., Ždìmal, V., Eleftheriadis, K., Lazaridis, M., Dye, C., and Mihalopoulos, N.: Chemical composition of size-resolved atmospheric aerosols in the eastern Mediterranean during summer and winter, Atmos. Environ., 37, 195-208, https://doi.org/10.1016/s1352-2310(02)00859-2, 2003b.

Bates, T. S., Lamb, B. K., Guenther, A., Dignon, J., and Stoiber, R. E.: Sulfur emissions to the atmosphere from natural sourees, J. Atmos. Chem., 14, 315-337, https://doi.org/10.1007/bf00115242, 2004.

Bautista, A. T., Pabroa, P. C. B., Santos, F. L., Racho, J. M. D., and Quirit, L. L.: Carbonaceous particulate matter characterization in an urban and a rural site in the Philippines, Atmos. Pollut. Res., 5, 245-252, https://doi.org/10.5094/apr.2014.030, 2014.

Beaver, M. R., Garland, R. M., Hasenkopf, C. A., Baynard, T., Ravishankara, A. R., and Tolbert, M. A.: A laboratory investigation 
of the relative humidity dependence of light extinction by organic compounds from lignin combustion, Environ. Res. Lett., 3, 045003, https://doi.org/10.1088/1748-9326/3/4/045003, 2008.

Berresheim, H.: Biogenic sulfur emissions from the Subantarctic and Antarctic Oceans, J. Geophys. Res., 92, 13245-13262, https://doi.org/10.1029/JD092iD11p13245, 1987.

Bikkina, S., Kawamura, K., Miyazaki, Y., and Fu, P.: High abundances of oxalic, azelaic, and glyoxylic acids and methylglyoxal in the open ocean with high biological activity: Implication for secondary OA formation from isoprene, Geophys. Res. Lett., 41, 3649-3657, https://doi.org/10.1002/2014g1059913, 2014.

Biona, J. B., Mejia, M., Tacderas, M., dela Cruz, N., Dematera, K., and Romero, J.: Alternative Technologies for the Philippine Utility Jeepney: A Cost-Benefit Study; Blacksmith Institute and Clean Air Asia: Pasig City, Philippines, available at: https://cleanairasia.org/wp-content/uploads/2017/ 04/Jeepney-CB-Study.pdf (last access: 1 July 2020), 2017.

Blando, J. D. and Turpin, B. J.: Secondary organic aerosol formation in cloud and fog droplets: a literature evaluation of plausibility, Atmos. Environ., 34, 1623-1632, https://doi.org/10.1016/s1352-2310(99)00392-1, 2000.

Braun, R. A., Aghdam, M. A., Bañaga, P. A., Betito, G., Cambaliza, M. O., Cruz, M. T., Lorenzo, G. R., MacDonald, A. B., Simpas, J. B., Stahl, C., and Sorooshian, A.: Long-range aerosol transport and impacts on size-resolved aerosol composition in Metro Manila, Philippines, Atmos. Chem. Phys., 20, 2387-2405, https://doi.org/10.5194/acp-20-2387-2020, 2020.

Brown, S. G., Eberly, S., Paatero, P., and Norris, G. A.: Methods for estimating uncertainty in PMF solutions: examples with ambient air and water quality data and guidance on reporting PMF results, Sci. Total Environ., 518, 626-635, https://doi.org/10.1016/j.scitotenv.2015.01.022, 2015.

Cai, C., Marsh, A., Zhang, Y. H., and Reid, J. P.: Group Contribution Approach To Predict the Refractive Index of Pure Organic Components in Ambient Organic Aerosol, Environ. Sci. Technol., 51, 9683-9690, https://doi.org/10.1021/acs.est.7b01756, 2017.

Carlton, A. G., Turpin, B. J., Lim, H.-J., Altieri, K. E., and Seitzinger, S.: Link between isoprene and secondary organic aerosol (SOA): Pyruvic acid oxidation yields low volatility organic acids in clouds, Geophys. Res. Lett., 33, L06822, https://doi.org/10.1029/2005g1025374, 2006.

Chebbi, A. and Carlier, P.: Carboxylic acids in the troposphere, occurrence, sources, and sinks: A review, Atmos. Environ., 30, 4233-4249, https://doi.org/10.1016/1352-2310(96)00102-1, 1996.

Chow, J. C., Watson, J. G., Kuhns, H., Etyemezian, V., Lowenthal, D. H., Crow, D., Kohl, S. D., Engelbrecht, J. P., and Green, M. C.: Source profiles for industrial, mobile, and area sources in the Big Bend Regional Aerosol Visibility and Observational study, Chemosphere, 54, 185-208, https://doi.org/10.1016/j.chemosphere.2003.07.004, 2004.

Claeys, M., Vermeylen, R., Yasmeen, F., Gómez-González, Y., Chi, X., Maenhaut, W., Mészáros, T., and Salma, I.: Chemical characterisation of humic-like substances from urban, rural and tropical biomass burning environments using liquid chromatography with UV/vis photodiode array detection and electrospray ionisation mass spectrometry, Environ. Chem., 9, 273-284, https://doi.org/10.1071/en11163, 2012.
Cohen, D. D., Stelcer, E., Santos, F. L., Prior, M., Thompson, C., and Pabroa, P. C. B.: Fingerprinting and source apportionment of fine particle pollution in Manila by IBA and PMF techniques: A 7-year study, X-Ray Spectrom, 38, 18-25, https://doi.org/10.1002/xrs.1112, 2009.

Crosbie, E., Sorooshian, A., Monfared, N. A., Shingler, T., and Esmaili, O.: A multi-year aerosol characterization for the greater Tehran area using satellite, surface, and modeling data, Atmosphere, 5, 178-197, https://doi.org/10.3390/atmos5020178, 2014.

Cruz, F. T., Narisma, G. T., Villafuerte, M. Q., Cheng Chua, K. U., and Olaguera, L. M.: A climatological analysis of the southwest monsoon rainfall in the Philippines, Atmos. Res., 122, 609-616, https://doi.org/10.1016/j.atmosres.2012.06.010, 2013.

Cruz, M. T., Bañaga, P. A., Betito, G., Braun, R. A., Stahl, C., Aghdam, M. A., Cambaliza, M. O., Dadashazar, H., Hilario, M. R., Lorenzo, G. R., Ma, L., MacDonald, A. B., Pabroa, P. C., Yee, J. R., Simpas, J. B., and Sorooshian, A.: Size-resolved composition and morphology of particulate matter during the southwest monsoon in Metro Manila, Philippines, Atmos. Chem. Phys., 19, 10675-10696, https://doi.org/10.5194/acp-19-106752019, 2019.

Dasgupta, P. K., Campbell, S. W., Al-Horr, R. S., Ullah, S. M. R., Li, J., Amalfitano, C., and Poor, N. D.: Conversion of sea salt aerosol to $\mathrm{NaNO} 3$ and the production of $\mathrm{HCl}$ : Analysis of temporal behavior of aerosol chloride/nitrate and gaseous $\mathrm{HCl} / \mathrm{HNO}_{3}$ concentrations with AIM, Atmos. Environ., 41, 4242-4257, https://doi.org/10.1016/j.atmosenv.2006.09.054, 2007.

Davis, D., Chen, G., Kasibhatla, P., Jefferson, A., Tanner, D., Eisele, F., Lenschow, D., Neff, W., and Berresheim, H.: DMS oxidation in the Antarctic marine boundary layer: Comparison of model simulations and held observations of DMS, DMSO, $\mathrm{DMSO}_{2}$, $\mathrm{H}_{2} \mathrm{SO}_{4}(\mathrm{~g})$, MSA(g), and MSA(p), J. Geophys. Res.-Atmos., 103, 1657-1678, https://doi.org/10.1029/97jd03452, 1998.

Dawson, M. L., Varner, M. E., Perraud, V., Ezell, M. J., Gerber, R. B., and Finlayson-Pitts, B. J.: Simplified mechanism for new particle formation from methanesulfonic acid, amines, and water via experiments and ab initio calculations, P. Natl. Acad. Sci. USA, 109, 18719-18724, https://doi.org/10.1073/pnas.1211878109, 2012.

De Bruyn, W. J., Shorter, J. A., Davidovits, P., Worsnop, D. R., Zahniser, M. S., and Kolb, C. E.: Uptake of gas phase sulfur species methanesulfonic acid, dimethylsulfoxide, and dimethyl sulfone by aqueous surfaces, J. Geophys. Res., 99, 16927-16932, https://doi.org/10.1029/94jd00684, 1994.

Decesari, S., Fuzzi, S., Facchini, M. C., Mircea, M., Emblico, L., Cavalli, F., Maenhaut, W., Chi, X., Schkolnik, G., Falkovich, A., Rudich, Y., Claeys, M., Pashynska, V., Vas, G., Kourtchev, I., Vermeylen, R., Hoffer, A., Andreae, M. O., Tagliavini, E., Moretti, F., and Artaxo, P.: Characterization of the organic composition of aerosols from Rondônia, Brazil, during the LBA-SMOCC 2002 experiment and its representation through model compounds, Atmos. Chem. Phys., 6, 375-402, https://doi.org/10.5194/acp-6-375-2006, 2006.

Deshmukh, D. K., Kawamura, K., Lazaar, M., Kunwar, B., and Boreddy, S. K. R.: Dicarboxylic acids, oxoacids, benzoic acid, $\alpha$-dicarbonyls, WSOC, OC, and ions in spring aerosols from Okinawa Island in the western North Pacific Rim: size distributions 
and formation processes, Atmos. Chem. Phys., 16, 5263-5282, https://doi.org/10.5194/acp-16-5263-2016, 2016.

Dimitriou, K.: The dependence of PM size distribution from meteorology and local-regional contributions, in Valencia (Spain)-A CWT model approach, Aerosol. Air. Qual. Res., 15, 1979-1989, https://doi.org/10.4209/aaqr.2015.03.0162, 2015.

Dimitriou, K., Remoundaki, E., Mantas, E., and Kassomenos, P.: Spatial distribution of source areas of $\mathrm{PM}_{2.5}$ by Concentration Weighted Trajectory (CWT) model applied in $\mathrm{PM}_{2.5}$ concentration and composition data, Atmos. Environ., 116, 138-145, https://doi.org/10.1016/j.atmosenv.2015.06.021, 2015.

Ding, X. X., Kong, L. D., Du, C. T., Zhanzakova, A., Fu, H. B., Tang, X. F., Wang, L., Yang, X., Chen, J. M., and Cheng, T. T.: Characteristics of size-resolved atmospheric inorganic and carbonaceous aerosols in urban Shanghai, Atmos. Environ., 167, 625-641, https://doi.org/10.1016/j.atmosenv.2017.08.043, 2017.

Drozd, G., Woo, J., Häkkinen, S. A. K., Nenes, A., and McNeill, V. F.: Inorganic salts interact with oxalic acid in submicron particles to form material with low hygroscopicity and volatility, Atmos. Chem. Phys., 14, 5205-5215, https://doi.org/10.5194/acp14-5205-2014, 2014.

Du, Z., He, K., Cheng, Y., Duan, F., Ma, Y., Liu, J., Zhang, X., Zheng, M., and Weber, R.: A yearlong study of water-soluble organic carbon in Beijing I: Sources and its primary vs. secondary nature, Atmos. Environ., 92, 514-521, 2014.

Echalar, F., Gaudichet, A., Cachier, H., and Artaxo, P.: Aerosol emissions by tropical forest and savanna biomass burning: Characteristic trace elements and fluxes, Geophys. Res. Lett., 22, 3039-3042, https://doi.org/10.1029/95g103170, 1995.

Ervens, B., Feingold, G., Clegg, S. L., and Kreidenweis, S. M.: A modeling study of aqueous production of dicarboxylic acids: 2. Implications for cloud microphysics, J. Geophys. Res., 109, D15206, https://doi.org/10.1029/2004jd004575, 2004.

Ervens, B., Sorooshian, A., Lim, Y. B., and Turpin, B. J.: Key parameters controlling $\mathrm{OH}$-initiated formation of secondary organic aerosol in the aqueous phase (aqSOA), J. Geophys. Res.Atmos., 119, 3997-4016, https://doi.org/10.1002/2013jd021021, 2014.

Ervens, B.: Progress and Problems in Modeling Chemical Processing in Cloud Droplets and Wet Aerosol Particles, in: Multiphase Environmental Chemistry in the Atmosphere, ACS Symposium Series, ACS Publications, 327-345, 2018.

Falkovich, A. H., Schkolnik, G., Ganor, E., and Rudich, Y.: Adsorption of organic compounds pertinent to urban environments onto mineral dust particles, J. Geophys. Res., 109, D02208, https://doi.org/10.1029/2003jd003919, 2004

Falkovich, A. H., Graber, E. R., Schkolnik, G., Rudich, Y., Maenhaut, W., and Artaxo, P.: Low molecular weight organic acids in aerosol particles from Rondônia, Brazil, during the biomassburning, transition and wet periods, Atmos. Chem. Phys., 5, 781797, https://doi.org/10.5194/acp-5-781-2005, 2005.

Fine, P. M., Chakrabarti, B., Krudysz, M., Schauer, J. J., and Sioutas, C.: Diurnal variations of individual organic compound constituents of ultrafine and accumulation mode particulate matter in the Los Angeles Basin, Environ. Sci. Technol., 38, 12961304, https://doi.org/10.1021/es0348389, 2004.

Fitzgerald, J. W.: Marine aerosols: A review, Atmos. Environ., 25, 533-545, https://doi.org/10.1016/0960-1686(91)90050-h, 1991.
Fossum, K. N., Ovadnevaite, J., Ceburnis, D., Dall'Osto, M., Marullo, S., Bellacicco, M., Simo, R., Liu, D., Flynn, M., Zuend, A., and O'Dowd, C.: Summertime Primary and Secondary Contributions to Southern Ocean Cloud Condensation Nuclei, Sci. Rep., 8, 13844, https://doi.org/10.1038/s41598-01832047-4, 2018.

Freedman, M. A., Hasenkopf, C. A., Beaver, M. R., and Tolbert, M. A.: Optical properties of internally mixed aerosol particles composed of dicarboxylic acids and ammonium sulfate, J. Phys. Chem. A, 113, 13584-13592, https://doi.org/10.1021/jp906240y, 2009.

Fu, P. Q., Kawamura, K., Chen, J., Li, J., Sun, Y. L., Liu, Y., Tachibana, E., Aggarwal, S. G., Okuzawa, K., Tanimoto, H., Kanaya, Y., and Wang, Z. F.: Diurnal variations of organic molecular tracers and stable carbon isotopic composition in atmospheric aerosols over Mt. Tai in the North China Plain: an influence of biomass burning, Atmos. Chem. Phys., 12, 8359-8375, https://doi.org/10.5194/acp-12-8359-2012, 2012.

Gao, S., Hegg, D. A., Hobbs, P. V., Kirchstetter, T. W., Magi, B. I., and Sadilek, M.: Water-soluble organic components in aerosols associated with savanna fires in southern Africa: Identification, evolution, and distribution, J. Geophys. Res.-Atmos., 108, 8491, https://doi.org/10.1029/2002jd002324, 2003.

Gao, Y., Arimoto, R., Duce, R. A., Chen, L. Q., Zhou, M. Y., and Gu, D. Y.: Atmospheric non-sea-salt sulfate, nitrate and methanesulfonate over the China Sea, J. Geophys. Res.-Atmos., 101, 12601-12611, https://doi.org/10.1029/96jd00866, 1996.

Ge, C., Wang, J., Reid, J. S., Posselt, D. J., Xian, P., and Hyer, E.: Mesoscale modeling of smoke transport from equatorial Southeast Asian Maritime Continent to the Philippines: First comparison of ensemble analysis with in situ observations, J. Geophys. Res.-Atmos., 122, 5380-5398, https://doi.org/10.1002/2016jd026241, 2017.

Gelencsér and Varga: Evaluation of the atmospheric significance of multiphase reactions in atmospheric secondary organic aerosol formation, Atmos. Chem. Phys., 5, 2823-2831, https://doi.org/10.5194/acp-5-2823-2005, 2005.

Golly, B., Waked, A., Weber, S., Samake, A., Jacob, V., Conil, S., Rangognio, J., Chrétien, E., Vagnot, M. P., Robic, P. Y., Besombes, J. L., and Jaffrezo, J. L.: Organic markers and OC source apportionment for seasonal variations of $\mathrm{PM}_{2.5}$ at 5 rural sites in France, Atmos. Environ., 198, 142-157, https://doi.org/10.1016/j.atmosenv.201810.027, 2019.

Gondwe, M., Krol, M., Klaassen, W., Gieskes, W., and de Baar, H.: Comparison of modeled versus measured MSA:nss $\mathrm{SO}_{4}=$ ratios: A global analysis, Global Biogeochem. Cy., 18, GB2006, https://doi.org/10.1029/2003gb002144, 2004.

Graham, B., Mayol-Bracero, O. L., Guyon, P., Roberts, G. C., Decesari, S., Facchini, M. C., Artaxo, P., Maenhaut, W., Koll, P., and Andreae, M. O.: Water-soluble organic compounds in biomass burning aerosols over Amazonia1. Characterization by NMR and GC-MS, J. Geophys. Res., 107, 14-16, https://doi.org/10.1029/2001jd000336, 2002.

Greenfield, S. M.: Rain scavenging of radioactive particulate matter from the atmosphere, J. Meteorol., 14, 115-125, https://doi.org/10.1175/1520-0469(1957)0142.0.CO, 1957.

Grosjean, D., Van Cauwenberghe, K., Schmid, J. P., Kelley, P. E., and Pitts, J. N.: Identification of $\mathrm{C}_{3}-\mathrm{C}_{10}$ aliphatic dicarboxylic 
acids in airborne particulate matter, Environ. Sci. Technol., 12, 313-317, https://doi.org/10.1021/es60139a005, 1978.

Gullett, B. K., Linak, W. P., Touati, A., Wasson, S. J., Gatica, S., and King, C. J.: Characterization of air emissions and residual ash from open burning of electronic wastes during simulated rudimentary recycling operations, J. Mater. Cycles Waste., 9, 69-79, https://doi.org/10.1007/s10163-006-0161-x, 2007.

Hanson, D. R.: Mass accommodation of $\mathrm{H}_{2} \mathrm{SO}_{4}$ and $\mathrm{CH} 3 \mathrm{SO} 3 \mathrm{H}$ on water-sulfuric acid solutions from $6 \%$ to $97 \% \mathrm{RH}$, J. Phys. Chem. A, 109, 6919-6927, https://doi.org/10.1021/jp0510443, 2005.

Harrison, R. M., Beddows, D. C., and Dall'Osto, M.: PMF analysis of wide-range particle size spectra collected on a major highway, Environ. Sci. Technol., 45, 5522-5528, https://doi.org/10.1021/es2006622, 2011.

Hatakeyama, S., Ohno, M., Weng, J., Takagi, H., and Akimoto, H.: Mechanism for the formation of gaseous and particulate products from ozone-cycloalkene reactions in air, Environ. Sci. Technol., 21, 52-57, https://doi.org/10.1021/es00155a005, 1987.

Hegde, P., Kawamura, K., Girach, I., and Nair, P. R.: Characterisation of water-soluble organic aerosols at a site on the southwest coast of India, J. Atmos. Chem., 73, 181-205, 2016.

Hilario, M. R. A., Cruz, M. T., Bañaga, P. A., Betito, G., Braun, R. A., Stahl, C., Cambaliza, M. O., Lorenzo, G. R., MacDonald, A. B., AzadiAghdam, M., Pabroa, P. C., Yee, J. R., Simpas, J. B., and Sorooshian, A.: Characterizing weekly cycles of particulate matter in a coastal megacity: The importance of a seasonal, size-resolved, and chemically-speciated analysis, J. Geophys. Res.-Atmos., 125, e2020JD032614, https://doi.org/10.1029/2020JD032614, 2020a.

Hilario, M. R. A., Cruz, M. T., Cambaliza, M. O. L., Reid, J. S., Xian, P., Simpas, J. B., Lagrosas, N. D., Uy, S. N. Y., Cliff, S., and Zhao, Y.: Investigating size-segregated sources of elemental composition of particulate matter in the South China Sea during the 2011 Vasco cruise, Atmos. Chem. Phys., 20, 1255-1276, https://doi.org/10.5194/acp-20-1255-2020, 2020b.

Ho, K. F., Lee, S. C., Cao, J. J., Kawamura, K., Watanabe, T., Cheng, Y., and Chow, J. C.: Dicarboxylic acids, ketocarboxylic acids and dicarbonyls in the urban roadside area of Hong Kong, Atmos. Environ., 40, 3030-3040, https://doi.org/10.1016/j.atmosenv.2005.11.069, 2006.

Hodshire, A. L., Campuzano-Jost, P., Kodros, J. K., Croft, B., Nault, B. A., Schroder, J. C., Jimenez, J. L., and Pierce, J. R.: The potential role of methanesulfonic acid (MSA) in aerosol formation and growth and the associated radiative forcings, Atmos. Chem. Phys., 19, 3137-3160, https://doi.org/10.5194/acp19-3137-2019, 2019.

Hoffmann, E. H., Tilgner, A., Schrodner, R., Brauer, P., Wolke, R., and Herrmann, H.: An advanced modeling study on the impacts and atmospheric implications of multiphase dimethyl sulfide chemistry, P. Natl. Acad. Sci. USA, 113, 11776-11781, https://doi.org/10.1073/pnas.1606320113, 2016.

Hoffmann, E. H., Tilgner, A., Vogelsberg, U., Wolke, R., and Herrmann, H.: Near-Explicit Multiphase Modeling of Halogen Chemistry in a Mixed Urban and Maritime Coastal Area, ACS Earth Space Chem., 3, 2452-2471, https://doi.org/10.1021/acsearthspacechem.9b00184, 2019.

Hopke, P. K., Cohen, D. D., Begum, B. A., Biswas, S. K., Ni, B., Pandit, G. G., Santoso, M., Chung, Y.-S., Rahman, S. A., Hamzah, M. S., Davy, P., Markwitz, A., Waheed, S., Siddique,
N., Santos, F. L., Pabroa, P. C. B., Seneviratne, M. C. S., Wimolwattanapun, W., Bunprapob, S., Vuong, T. B., and Markowicz, A.: Urban air quality in the Asian region, Sci. Total Environ., 409, 4140, https://doi.org/10.1016/j.scitotenv.2011.06.028, 2011.

Hsu, S. C., Liu, S. C., Huang, Y. T., Chou, C. C., Lung, S. C., Liu, T. H., Tu, J. Y., and Tsai, F.: Long-range southeastward transport of Asian biosmoke pollution: Signature detected by aerosol potassium in northern Taiwan, J. Geophys. Res.-Atmos., 114, D14301, https://doi.org/10.1029/2009JD011725, 2009.

Hsu, Y.-K., Holsen, T. M., and Hopke, P. K.: Comparison of hybrid receptor models to locate PCB sources in Chicago, Atmos. Environ., 37, 545-562, https://doi.org/10.1016/S13522310(02)00886-5, 2003.

Iijima, A., Sato, K., Yano, K., Tago, H., Kato, M., Kimura, H., and Furuta, N.: Particle size and composition distribution analysis of automotive brake abrasion dusts for the evaluation of antimony sources of airborne particulate matter, Atmos. Environ., 41, 4908-4919, https://doi.org/10.1016/j.atmosenv.2007.02.005, 2007.

Kautzman, K. E., Surratt, J. D., Chan, M. N., Chan, A. W., Hersey, S. P., Chhabra, P. S., Dalleska, N. F., Wennberg, P. O., Flagan, R. C., and Seinfeld, J. H.: Chemical composition of gas- and aerosol-phase products from the photooxidation of naphthalene, J. Phys. Chem. A, 114, 913-934, https://doi.org/10.1021/jp908530s, 2010.

Kavouras, I. G. and Stephanou, E. G.: Particle size distribution of organic primary and secondary aerosol constituents in urban, background marine, and forest atmosphere, J. Geophys. Res., 107, 4069, https://doi.org/10.1029/2000jd000278, 2002.

Kawamura, K. and Kaplan, I. R.: Motor exhaust emissions as a primary source for dicarboxylic acids in Los Angeles ambient air, Environ. Sci. Technol., 21, 105-110, https://doi.org/10.1021/es00155a014, 1987.

Kawamura, K. and Ikushima, K.: Seasonal changes in the distribution of dicarboxylic acids in the urban atmosphere, Environ. Sci. Technol., 27, 2227-2235, https://doi.org/10.1021/es00047a033, 2002.

Kawamura, K., Imai, Y., and Barrie, L. A.: Photochemical production and loss of organic acids in high Arctic aerosols during longrange transport and polar sunrise ozone depletion events, Atmos. Environ., 39, 599-614, 2005.

Kawamura, K. and Yasui, O.: Diurnal changes in the distribution of dicarboxylic acids, ketocarboxylic acids and dicarbonyls in the urban Tokyo atmosphere, Atmos. Environ., 39, 1945-1960, https://doi.org/10.1016/j.atmosenv.2004.12.014, 2005.

Kawamura, K., Tachibana, E., Okuzawa, K., Aggarwal, S. G., Kanaya, Y., and Wang, Z. F.: High abundances of water-soluble dicarboxylic acids, ketocarboxylic acids and $\alpha$-dicarbonyls in the mountaintop aerosols over the North China Plain during wheat burning season, Atmos. Chem. Phys., 13, 8285-8302, https://doi.org/10.5194/acp-13-8285-2013, 2013.

Kawamura, K. and Bikkina, S.: A review of dicarboxylic acids and related compounds in atmospheric aerosols: Molecular distributions, sources and transformation, Atmos. Res., 170, 140-160, https://doi.org/10.1016/j.atmosres.2015.11.018, 2016.

Kecorius, S., Madueño, L., Vallar, E., Alas, H., Betito, G., Birmili, W., Cambaliza, M. O., Catipay, G., Gonzaga-Cayetano, M., Galvez, M. C., Lorenzo, G., Müller, T., Simpas, J. B., 
Tamayo, E. G., and Wiedensohler, A.: Aerosol particle mixing state, refractory particle number size distributions and emission factors in a polluted urban environment: Case study of Metro Manila, Philippines, Atmos. Environ., 170, 169-183, https://doi.org/10.1016/j.atmosenv.2017.09.037, 2017.

Kerminen, V.-M., Teinilä, K., Hillamo, R., and Mäkelä, T.: Size-segregated chemistry of particulate dicarboxylic acids in the Arctic atmosphere, Atmos. Environ., 33, 2089-2100, https://doi.org/10.1016/s1352-2310(98)00350-1, 1999.

Kerminen, V.-M., Aurela, M., Hillamo, R. E., and Virkkula, A.: Formation of particulate MSA: deductions from size distribution measurements in the Finnish Arctic, Tellus B, 49, 159-171, https://doi.org/10.3402/tellusb.v49i2.15959, 2017.

Kim Oanh, N. T., Upadhyay, N., Zhuang, Y. H., Hao, Z. P., Murthy, D. V. S., Lestari, P., Villarin, J. T., Chengchua, K., Co, H. X., and Dung, N. T.: Particulate air pollution in six Asian cities: Spatial and temporal distributions, and associated sources, Atmos. Environ., 40, 3367-3380, https://doi.org/10.1016/j.atmosenv.2006.01.050, 2006.

Kleindienst, T. E., Jaoui, M., Lewandowski, M., Offenberg, J. H., and Docherty, K. S.: The formation of SOA and chemical tracer compounds from the photooxidation of naphthalene and its methyl analogs in the presence and absence of nitrogen oxides, Atmos. Chem. Phys., 12, 8711-8726, https://doi.org/10.5194/acp-12-8711-2012, 2012.

Kobayashi, H., Matsunaga, T., Hoyano, A., Aoki, M., Komori, D., and Boonyawat, S.: Satellite estimation of photosynthetically active radiation in Southeast Asia: Impacts of smoke and cloud cover, J. Geophys. Res.-Atmos., 109, D04102, https://doi.org/10.1029/2003jd003807, 2004.

Kumar, S., Aggarwal, S. G., Gupta, P. K., and Kawamura, K.: Investigation of the tracers for plastic-enriched waste burning aerosols, Atmos. Environ., 108, 49-58, https://doi.org/10.1016/j.atmosenv.2015.02.066, 2015.

Kundu, S., Kawamura, K., Andreae, T. W., Hoffer, A., and Andreae, M. O.: Molecular distributions of dicarboxylic acids, ketocarboxylic acids and $\alpha$-dicarbonyls in biomass burning aerosols: implications for photochemical production and degradation in smoke layers, Atmos. Chem. Phys., 10, 2209-2225, https://doi.org/10.5194/acp-10-2209-2010, 2010.

Kunwar, B., Kawamura, K., Fujiwara, S., Fu, P., Miyazaki, Y., and Pokhrel, A.: Dicarboxylic acids, oxocarboxylic acids and $\alpha$-dicarbonyls in atmospheric aerosols from Mt. Fuji, Japan: Implication for primary emission versus secondary formation, Atmos. Res., 221, 58-71, https://doi.org/10.1016/j.atmosres.2019.01.021, 2019.

Li, J., Wang, G., Zhang, Q., Li, J., Wu, C., Jiang, W., Zhu, T., and Zeng, L.: Molecular characteristics and diurnal variations of organic aerosols at a rural site in the North China Plain with implications for the influence of regional biomass burning, Atmos. Chem. Phys., 19, 10481-10496, https://doi.org/10.5194/acp-1910481-2019, 2019.

Limbeck, A., Puxbaum, H., Otter, L., and Scholes, M. C.: Semivolatile behavior of dicarboxylic acids and other polar organic species at a rural background site (Nylsvley, RSA), Atmos. Environ., 35, 1853-1862, https://doi.org/10.1016/s13522310(00)00497-0, 2001

Linak, W. P., Miller, C. A., and Wendt, J. O.: Comparison of particle size distributions and elemental partition- ing from the combustion of pulverized coal and residual fuel oil, J. Air Waste. Manag. Assoc., 50, 1532-1544, https://doi.org/10.1080/10473289.2000.10464171, 2000.

Liu, Y., Minofar, B., Desyaterik, Y., Dames, E., Zhu, Z., Cain, J. P., Hopkins, R. J., Gilles, M. K., Wang, H., Jungwirth, P., and Laskin, A.: Internal structure, hygroscopic and reactive properties of mixed sodium methanesulfonate-sodium chloride particles, Phys. Chem. Chem. Phys., 13, 11846-11857, https://doi.org/10.1039/c1cp20444k, 2011.

Ma, L., Dadashazar, H., Braun, R. A., MacDonald, A. B., Aghdam, M. A., Maudlin, L. C., and Sorooshian, A.: Sizeresolved characteristics of water-soluble particulate elements in a coastal area: Source identification, influence of wildfires, and diurnal variability, Atmos. Environ., 206, 72-84, https://doi.org/10.1016/j.atmosenv.2019.02.045, 2019.

Madueño, L., Kecorius, S., Birmili, W., Müller, T., Simpas, J., Vallar, E., Galvez, M. C., Cayetano, M., and Wiedensohler, A.: Aerosol Particle and Black Carbon Emission Factors of Vehicular Fleet in Manila, Philippines, Atmosphere, 10, 603, https://doi.org/10.3390/atmos10100603, 2019.

Mahowald, N., Jickells, T. D., Baker, A. R., Artaxo, P., BenitezNelson, C. R., Bergametti, G., Bond, T. C., Chen, Y., Cohen, D. D., Herut, B., Kubilay, N., Losno, R., Luo, C., Maenhaut, W., McGee, K. A., Okin, G. S., Siefert, R. L., and Tsukuda, S.: Global distribution of atmospheric phosphorus sources, concentrations and deposition rates, and anthropogenic impacts, Global Biogeochem. Cy., 22, GB4026, https://doi.org/10.1029/2008gb003240, 2008.

Malm, W. C., Sisler, J. F., Huffman, D., Eldred, R. A., and Cahill, T. A.: Spatial and seasonal trends in particle concentration and optical extinction in the United States, J. Geophys. Res.-Atmos., 99, 1347-1370, https://doi.org/10.1029/93jd02916, 1994.

Mardi, A. H., Dadashazar, H., MacDonald, A. B., Braun, R. A., Crosbie, E., Xian, P., Thorsen, T. J., Coggon, M. M., Fenn, M. A., Ferrare, R. A., Hair, J. W., Woods, R. K., Jonsson, H. H., Flagan, R. C., Seinfeld, J. H., and Sorooshian, A.: Biomass Burning Plumes in the Vicinity of the California Coast: Airborne Characterization of Physicochemical Properties, Heating Rates, and Spatiotemporal Features, J. Geophys. Res.-Atmos., 123, 1356013582, https://doi.org/10.1029/2018jd029134, 2018.

Marple, V., Olson, B., Romay, F., Hudak, G., Geerts, S. M., and Lundgren, D.: Second Generation Micro-Orifice Uniform Deposit Impactor, 120 MOUDI-II: Design, Evaluation, and Application to Long-Term Ambient Sampling, Aerosol Sci. Tech., 48, 427-433, https://doi.org/10.1080/02786826.2014.884274, 2014.

Marsh, A., Miles, R. E. H., Rovelli, G., Cowling, A. G., Nandy, L., Dutcher, C. S., and Reid, J. P.: Influence of organic compound functionality on aerosol hygroscopicity: dicarboxylic acids, alkyl-substituents, sugars and amino acids, Atmos. Chem. Phys., 17, 5583-5599, https://doi.org/10.5194/acp17-5583-2017, 2017.

Marsh, A., Rovelli, G., Miles, R. E. H., and Reid, J. P.: Complexity of Measuring and Representing the Hygroscopicity of Mixed Component Aerosol, J. Phys. Chem. A, 123, 1648-1660, https://doi.org/10.1021/acs.jpca.8b11623, 2019.

Matsumoto, J., Olaguera, L. M. P., Nguyen-Le, D., Kubota, H., and Villafuerte, M. Q.: Climatological seasonal changes of wind and rainfall in the Philippines, Int. J. Climatol., 40, 4843-4857, https://doi.org/10.1002/joc.6492, 2020. 
Maudlin, L. C., Wang, Z., Jonsson, H. H., and Sorooshian, A.: Impact of wildfires on size-resolved aerosol composition at a coastal California site, Atmos. Environ., 119, 59-68, https://doi.org/10.1016/j.atmosenv.2015.08.039, 2015.

McGinty, S. M., Kapala, M. K., and Niedziela, R. F.: Mid-infrared complex refractive indices for oleic acid and optical properties of model oleic acid/water aerosols, Phys. Chem. Chem. Phys., 11, 7998-8004, https://doi.org/10.1039/b905371a, 2009.

Miljevic, B., Hedayat, F., Stevanovic, S., Fairfull-Smith, K. E., Bottle, S., and Ristovski, Z.: To sonicate or not to sonicate PM filters: Reactive oxygen species generation upon ultrasonic irradiation, Aerosol Sci. Tech., 48, 1276-1284, https://doi.org/10.1080/02786826.2014.981330, 2014.

Mochida, M., Umemoto, N., Kawamura, K., and Uematsu, M.: Bimodal size distribution of C2-C4 dicarboxylic acids in the marine aerosols, Geophys. Res. Lett., 30, 1672, https://doi.org/10.1029/2003g1017451, 2003.

Mooibroek, D., Schaap, M., Weijers, E. P., and Hoogerbrugge, R.: Source apportionment and spatial variability of $\mathrm{PM}_{2.5}$ using measurements at five sites in the Netherlands, Atmos. Environ., 45, 4180-4191, https://doi.org/10.1016/j.atmosenv.2011.05.017, 2011.

Mora, M., Braun, R. A., Shingler, T., and Sorooshian, A.: Analysis of remotely sensed and surface data of aerosols and meteorology for the Mexico Megalopolis Area between 2003 and 2015, J. Geophys. Res.-Atmos., 122, 8705-8723, https://doi.org/10.1002/2017JD026739, 2017.

Myhre, C. E. L. and Nielsen, C. J.: Optical properties in the UV and visible spectral region of organic acids relevant to tropospheric aerosols, Atmos. Chem. Phys., 4, 1759-1769, https://doi.org/10.5194/acp-4-1759-2004, 2004.

Narukawa, M., Kawamura, K., Takeuchi, N., and Nakajima, T.: Distribution of dicarboxylic acids and carbon isotopic compositions in aerosols from 1997 Indonesian forest fires, Geophys. Res. Lett., 26, 3101-3104, https://doi.org/10.1029/1999gl010810, 1999.

Neusüss, C., Pelzing, M., Plewka, A., and Herrmann, H.: A new analytical approach for size-resolved speciation of organic compounds in atmospheric aerosol particles: Methods and first results, J. Geophys. Res.-Atmos., 105, 4513-4527, https://doi.org/10.1029/1999jd901038, 2000.

Nguyen, D. L., Kawamura, K., Ono, K., Ram, S. S., Engling, G., Lee, C.-T., Lin, N.-H., Chang, S.-C., Chuang, M.-T., and Hsiao, T.-C.: Comprehensive $\mathrm{PM}_{2.5}$ organic molecular composition and stable carbon isotope ratios at Sonla, Vietnam: Fingerprint of biomass burning components, Aerosol. Air. Qual. Res., 16, 2618-2634, https://doi.org/10.4209/aaqr.2015.07.04592016.

Norton, R. B., Roberts, J. M., and Huebert, B. J.: Tropospheric oxalate, Geophys. Res. Lett., 10, 517-520, https://doi.org/10.1029/GL010i007p00517, 1983.

Ovadnevaite, J., Ceburnis, D., Leinert, S., Dall'Osto, M., Canagaratna, M., O'Doherty, S., Berresheim, H., and O'Dowd, C.: Submicron NE Atlantic marine aerosol chemical composition and abundance: Seasonal trends and air mass categorization, J. Geophys. Res.-Atmos., 119, 11850-11863, https://doi.org/10.1002/2013jd021330, 2014.

Paatero, P. and Tapper, U.: Positive matrix factorization: A nonnegative factor model with optimal utilization of error estimates of data values, Environmetrics, 5, 111-126, 1994.
Pabroa, P. C. B., Santos, F. L., Morco, R. P., Racho, J. M. D., Bautista Vii, A. T., and Bucal, C. G. D.: Receptor modeling studies for the characterization of air particulate lead pollution sources in Valenzuela sampling site (Philippines), Atmos. Pollut. Res., 2, 213-218, https://doi.org/10.5094/apr.2011.027, 2011.

PAGASA: Termination of the southwest monsoon: available at: http://bagong.pagasa.dost.gov.ph/press-release/30 (last access: 1 July 2020), 2018a.

PAGASA: Onset of the rainy season: available at: http://bagong. pagasa.dost.gov.ph/press-release/29 (last access: 1 July 2020), 2018 b.

PAGASA: Onset of the northeast monsoon: available at: http://bagong.pagasa.dost.gov.ph/press-release/32 (last access: 1 July 2020), 2018c.

PAGASA: Onset of the rainy season: available at: http://bagong. pagasa.dost.gov.ph/press-release/50 (last access: 1 July 2020), 2019a.

PAGASA: Transition to northeast monsoon: available at: http://bagong.pagasa.dost.gov.ph/press-release/56 (last access: 1 July 2020), 2019 b.

Paris, R. and Desboeufs, K.: Effect of atmospheric organic complexation on iron-bearing dust solubility, Atmos Chem Phys, 13, 4895-4905, https://doi.org/10.5194/acp-13-4895-2013, 2013.

Peng, C. and Chan, C. K.: The water cycles of water-soluble organic salts of atmospheric importance, Atmos. Environ., 35, 11831192, https://doi.org/10.1016/s1352-2310(00)00426-x, 2001.

Peng, C., Jing, B., Guo, Y. C., Zhang, Y. H., and Ge, M. F.: Hygroscopic Behavior of Multicomponent Aerosols Involving $\mathrm{NaCl}$ and Dicarboxylic Acids, J. Phys. Chem. A, 120, 1029-1038, https://doi.org/10.1021/acs.jpca.5b09373, 2016.

Pereira, W. E., Rostad, C. E., Taylor, H. E., and Klein, J. M.: Characterization of organic contaminants in environmental samples associated with Mount St. Helens 1980 volcanic eruption, Environ. Sci. Technol., 16, 387-396, https://doi.org/10.1021/es00101a005, 1982.

Prabhakar, G., Sorooshian, A., Toffol, E., Arellano, A. F., and Betterton, E. A.: Spatiotemporal Distribution of Airborne Particulate Metals and Metalloids in a Populated Arid Region, Atmos. Environ., 92, 339-347, https://doi.org/10.1016/j.atmosenv.2014.04.044, 2014.

Pratt, K. A., Murphy, S. M., Subramanian, R., DeMott, P. J., Kok, G. L., Campos, T., Rogers, D. C., Prenni, A. J., Heymsfield, A. J., Seinfeld, J. H., and Prather, K. A.: Flight-based chemical characterization of biomass burning aerosols within two prescribed burn smoke plumes, Atmos. Chem. Phys., 11, 1254912565, https://doi.org/10.5194/acp-11-12549-2011, 2011.

Prenni, A. J., DeMott, P. J., Kreidenweis, S. M., Sherman, D. E., Russell, L. M., and Ming, Y.: The Effects of Low Molecular Weight Dicarboxylic Acids on Cloud Formation, J. Phys. Chem. A, 105, 11240-11248, https://doi.org/10.1021/jp012427d, 2001.

PSA: Highlights of the Philippine population 2015 census of population: available at: https://psa.gov.ph/content/ highlights-philippine-population-2015-census-population, last access: 7 January 2016.

Ramachandran, S. and Rajesh, T. A.: Black carbon aerosol mass concentrations over Ahmedabad, an urban location in western India: Comparison with urban sites in Asia, Europe, Canada, and the United States, J. Geophys. Res., 112, D06211, https://doi.org/10.1029/2006jd007488, 2007. 
Ran, L., Deng, Z. Z., Wang, P. C., and Xia, X. A.: Black carbon and wavelength-dependent aerosol absorption in the North China Plain based on two-year aethalometer measurements, Atmos. Environ., 142, 132-144, https://doi.org/10.1016/j.atmosenv.2016.07.014, 2016.

Reff, A., Eberly, S. I., and Bhave, P. V.: Receptor modeling of ambient particulate matter data using positive matrix factorization: review of existing methods, J. Air Waste. Manag. Assoc., 57, 146154, https://doi.org/10.1080/10473289.2007.10465319, 2007.

Reid, J. S., Hobbs, P. V., Ferek, R. J., Blake, D. R., Martins, J. V., Dunlap, M. R., and Liousse, C.: Physical, chemical, and optical properties of regional hazes dominated by smoke in Brazil, J. Geophys. Res.-Atmos., 103, 32059-32080, https://doi.org/10.1029/98jd00458, 1998.

Reid, J. S., Koppmann, R., Eck, T. F., and Eleuterio, D. P.: A review of biomass burning emissions part II: intensive physical properties of biomass burning particles, Atmos. Chem. Phys., 5, 799825, https://doi.org/10.5194/acp-5-799-2005, 2005.

Reid, J. S., Hyer, E. J., Johnson, R. S., Holben, B. N., Yokelson, R. J., Zhang, J., Campbell, J. R., Christopher, S. A., Di Girolamo, L., Giglio, L., Holz, R. E., Kearney, C., Miettinen, J., Reid, E. A., Turk, F. J., Wang, J., Xian, P., Zhao, G., Balasubramanian, R., Chew, B. N., Janjai, S., Lagrosas, N., Lestari, P., Lin, N.H., Mahmud, M., Nguyen, A. X., Norris, B., Oanh, N. T. K., Oo, M., Salinas, S. V., Welton, E. J., and Liew, S. C.: Observing and understanding the Southeast Asian aerosol system by remote sensing: An initial review and analysis for the Seven Southeast Asian Studies (7SEAS) program, Atmos. Res., 122, 403-468, https://doi.org/10.1016/j.atmosres.2012.06.005, 2013.

Reid, J. S., Xian, P., Holben, B. N., Hyer, E. J., Reid, E. A., Salinas, S. V., Zhang, J., Campbell, J. R., Chew, B. N., Holz, R. E., Kuciauskas, A. P., Lagrosas, N., Posselt, D. J., Sampson, C. R., Walker, A. L., Welton, E. J., and Zhang, C.: Aerosol meteorology of the Maritime Continent for the 2012 7SEAS southwest monsoon intensive study - Part 1: regional-scale phenomena, Atmos. Chem. Phys., 16, 14041-14056, https://doi.org/10.5194/acp-1614041-2016, 2016.

Rogge, W. F., Mazurek, M. A., Hildemann, L. M., Cass, G. R., and Simoneit, B. R. T.: Quantification of urban organic aerosols at a molecular level: Identification, abundance and seasonal variation, Atmos. Environ., 27, 1309-1330, https://doi.org/10.1016/0960-1686(93)90257-y, 1993.

Rolph, G., Stein, A., and Stunder, B.: Real-time Environmental Applications and Display sYstem: READY, Environ. Modell Softw., 95, 210-228, https://doi.org/10.1016/j.envsoft.2017.06.025, 2017.

Rose, C., Chaumerliac, N., Deguillaume, L., Perroux, H., MouchelVallon, C., Leriche, M., Patryl, L., and Armand, P.: Modeling the partitioning of organic chemical species in cloud phases with CLEPS (1.1), Atmos. Chem. Phys., 18, 2225-2242, https://doi.org/10.5194/acp-18-2225-2018, 2018.

Russell, L. M., Maria, S. F., and Myneni, S. C. B.: Mapping organic coatings on atmospheric particles, Geophys. Res. Lett., 29, 2124, https://doi.org/10.1029/2002g1014874, 2002.

Saltzman, E. S., Savoie, D. L., Zika, R. G., and Prospero, J. M.: Methane sulfonic acid in the marine atmosphere, J. Geophys. Res.-Oceans, 88, 10897-10902, https://doi.org/10.1029/JC088iC15p10897, 1983.
Sareen, N., Carlton, A. G., Surratt, J. D., Gold, A., Lee, B., LopezHilfiker, F. D., Mohr, C., Thornton, J. A., Zhang, Z., Lim, Y. B., and Turpin, B. J.: Identifying precursors and aqueous organic aerosol formation pathways during the SOAS campaign, Atmos. Chem. Phys., 16, 14409-14420, https://doi.org/10.5194/acp-1614409-2016, 2016.

Saxena, P., and Hildemann, L. M.: Water-soluble organics in atmospheric particles: A critical review of the literature and application of thermodynamics to identify candidate compounds, J. Atmos. Chem., 24, 57-109, https://doi.org/10.1007/bf00053823, 1996.

Schlosser, J. S., Braun, R. A., Bradley, T., Dadashazar, H., MacDonald, A. B., Aldhaif, A. A., Aghdam, M. A., Mardi, A. H., Xian, P., and Sorooshian, A.: Analysis of aerosol composition data for western United States wildfires between 2005 and 2015: Dust emissions, chloride depletion, and most enhanced aerosol constituents, J. Geophys. Res.-Atmos., 122, 8951-8966, 2017.

Seinfeld, J. H. and Pandis, S. N.: Atmospheric chemistry and physics, 3rd ed., Wiley-Interscience, New York, 1152 pp., 2016.

Sempére, R. and Kawamura, K.: Comparative distributions of dicarboxylic acids and related polar compounds in snow, rain and aerosols from urban atmosphere, Atmos. Environ., 28, 449-459, https://doi.org/10.1016/1352-2310(94)90123-6, 1994.

Siffert, C. and Sulzberger, B.: Light-induced dissolution of hematite in the presence of oxalate. A case study, Langmuir, 7, 16271634, https://doi.org/10.1021/la00056a014, 1991.

Simoneit, B. R., Medeiros, P. M., and Didyk, B. M.: Combustion products of plastics as indicators for refuse burning in the atmosphere, Environ. Sci. Technol., 39, 6961-6970, https://doi.org/10.1021/es050767x, 2005.

Simpas, J., Lorenzo, G., and Cruz, M.: Monitoring Particulate Matter Levels and Composition for Source Apportionment Study in Metro Manila, Philippines, in: Improving Air Quality in Asian Developing Countries: Compilation of Research Findings, edited by: Kim Oanh, N. T., 239-261, 2014.

Singh, M., Jaques, P. A., and Sioutas, C.: Size distribution and diurnal characteristics of particle-bound metals in source and receptor sites of the Los Angeles Basin, Atmos. Environ., 36, 16751689, https://doi.org/10.1016/s1352-2310(02)00166-8, 2002.

Song, J., Zhao, Y., Zhang, Y., Fu, P., Zheng, L., Yuan, Q., Wang, S., Huang, X., Xu, W., Cao, Z., Gromov, S., and Lai, S.: Influence of biomass burning on atmospheric aerosols over the western South China Sea: Insights from ions, carbonaceous fractions and stable carbon isotope ratios, Environ. Pollut., 242, 1800-1809, https://doi.org/10.1016/j.envpol.2018.07.088, 2018.

Sorooshian, A., Varutbangkul, V., Brechtel, F. J., Ervens, B., Feingold, G., Bahreini, R., Murphy, S. M., Holloway, J. S., Atlas, E. L., Buzorius, G., Jonsson, H., Flagan, R. C., and Seinfeld, J. H.: Oxalic acid in clear and cloudy atmospheres: Analysis of data from International Consortium for Atmospheric Research on Transport and Transformation 2004, J. Geophys. Res.-Atmos., 111, D23S45, https://doi.org/10.1029/2005jd006880, 2006.

Sorooshian, A., Lu, M. L., Brechtel, F. J., Jonsson, H., Feingold, G., Flagan, R. C., and Seinfeld, J. H.: On the source of organic acid aerosol layers above clouds, Environ. Sci. Technol., 41, 46474654, https://doi.org/10.1021/es0630442, 2007a.

Sorooshian, A., Ng, N. L., Chan, A. W. H., Feingold, G., Flagan, R. C., and Seinfeld, J. H.: Particulate organic acids and overall water-soluble aerosol composition measurements from the 
2006 Gulf of Mexico Atmospheric Composition and Climate Study (GoMACCS), J. Geophys. Res.-Atmos., 112, D13201, https://doi.org/10.1029/2007jd008537, 2007b.

Sorooshian, A., Hersey, S., Brechtel, F. J., Corless, A., Flagan, R. C., and Seinfeld, J. H.: Rapid, Size-Resolved Aerosol Hygroscopic Growth Measurements: Differential Aerosol Sizing and Hygroscopicity Spectrometer Probe (DASH-SP), Aerosol Sci. Tech., 42, 445-464, https://doi.org/10.1080/02786820802178506, 2008.

Sorooshian, A., Padró, L. T., Nenes, A., Feingold, G., McComiskey, A., Hersey, S. P., Gates, H., Jonsson, H. H., Miller, S. D., Stephens, G. L., Flagan, R. C., and Seinfeld, J. H.: On the link between ocean biota emissions, aerosol, and maritime clouds: Airborne, ground, and satellite measurements off the coast of California, Global Biogeochem. Cy., 23, GB4007, https://doi.org/10.1029/2009gb003464, 2009.

Sorooshian, A., Murphy, S. M., Hersey, S., Bahreini, R., Jonsson, H., Flagan, R. C., and Seinfeld, J. H.: Constraining the contribution of organic acids and AMSm/z44 to the organic aerosol budget: On the importance of meteorology, aerosol hygroscopicity, and region, Geophys. Res. Lett., 37, L21807, https://doi.org/10.1029/2010g1044951, 2010.

Sorooshian, A., Wonaschutz, A., Jarjour, E. G., Hashimoto, B. I., Schichtel, B. A., and Betterton, E. A.: An aerosol climatology for a rapidly growing arid region (southern Arizona): Major aerosol species and remotely sensed aerosol properties, J. Geophys. Res.Atmos., 116, 16, https://doi.org/10.1029/2011JD016197, 2011.

Sorooshian, A., Wang, Z., Coggon, M. M., Jonsson, H. H., and Ervens, B.: Observations of sharp oxalate reductions in stratocumulus clouds at variable altitudes: organic acid and metal measurements during the 2011 E-PEACE campaign, Environ. Sci. Technol., 47, 7747-7756, https://doi.org/10.1021/es4012383, 2013.

Sorooshian, A., Crosbie, E., Maudlin, L. C., Youn, J. S., Wang, Z., Shingler, T., Ortega, A. M., Hersey, S., and Woods, R. K.: Surface and airborne measurements of organosulfur and methanesulfonate over the Western United States and coastal areas, J. Geophys. Res.-Atmos., 120, 8535-8548, https://doi.org/10.1002/2015JD023822, 2015.

Stahl, C., Cruz, M. T., Banaga, P. A., Betito, G., Braun, R. A., Aghdam, M. A., Cambaliza, M. O., Lorenzo, G. R., MacDonald, A. B., Pabroa, P. C., Yee, J. R., Simpas, J. B., and Sorooshian, A.: An annual time series of weekly size-resolved aerosol properties in the megacity of Metro Manila, Philippines, Sci. Data, 7, 128, https://doi.org/10.1038/s41597-020-0466-y, 2020a.

Stahl, C., Cruz, M. T., Banaga, P. A., Betito, G., Braun, R. A., Aghdam, M. A., Cambaliza, M. O., Lorenzo, G. R., MacDonald, A. B., Pabroa, P. C., Yee, J. R., Simpas, J. B., and Sorooshian, A., An annual time series of weekly size-resolved aerosol properties in the megacity of Metro Manila, Philippines, figshare, https://doi.org/10.6084/m9.figshare.11861859, 2020 b.

Stein, A. F., Draxler, R. R., Rolph, G. D., Stunder, B. J. B., Cohen, M. D., and Ngan, F.: NOAA's HYSPLIT Atmospheric Transport and Dispersion Modeling System, B. Am. Meteorol. Soc., 96, 2059-2077, https://doi.org/10.1175/bams-d-14-00110.1, 2015.

Streets, D. G., Carmichael, G. R., and Arndt, R. L.: Sulfur dioxide emissions and sulfur deposition from international shipping in Asian waters, Atmos. Environ., 31, 1573-1582, https://doi.org/10.1016/s1352-2310(96)00204-x, 1997.
Streets, D. G., Guttikunda, S. K., and Carmichael, G. R.: The growing contribution of sulfur emissions from ships in Asian waters, 1988-1995, Atmos. Environ., 34, 4425-4439, https://doi.org/10.1016/s1352-2310(00)00175-8, 2000.

Sullivan, R. C. and Prather, K. A.: Investigations of the diurnal cycle and mixing state of oxalic acid in individual particles in Asian aerosol outflow, Environ. Sci. Technol., 41, 8062-8069, https://doi.org/10.1021/es071134g, 2007.

Takahashi, K., Nansai, K., Tohno, S., Nishizawa, M., Kurokawa, J.-i., and Ohara, T.: Production-based emissions, consumptionbased emissions and consumption-based health impacts of $\mathrm{PM}_{2.5}$ carbonaceous aerosols in Asia, Atmos. Environ., 97, 406-415, https://doi.org/10.1016/j.atmosenv.2014.04.028, 2014.

Tang, M., Guo, L., Bai, Y., Huang, R.-J., Wu, Z., Wang, Z., Zhang, G., Ding, X., Hu, M., and Wang, X.: Impacts of methanesulfonate on the cloud condensation nucleation activity of sea salt aerosol, Atmos. Environ., 201, 13-17, https://doi.org/10.1016/j.atmosenv.2018.12.034, 2019.

Tang, M. J., Whitehead, J., Davidson, N. M., Pope, F. D., Alfarra, M. R., McFiggans, G., and Kalberer, M.: Cloud condensation nucleation activities of calcium carbonate and its atmospheric ageing products, Phys. Chem. Chem. Phys., 17, 32194-32203, https://doi.org/10.1039/c5cp03795f, 2015.

Thepnuan, D., Chantara, S., Lee, C. T., Lin, N. H., and Tsai, Y. I.: Molecular markers for biomass burning associated with the characterization of $\mathrm{PM}_{2.5}$ and component sources during dry season haze episodes in Upper South East Asia, Sci. Total Environ., 658, 708-722, https://doi.org/10.1016/j.scitotenv.2018.12.201, 2019.

Tsai, Y. I., Kuo, S.-C., Young, L.-H., Hsieh, L.-Y., and Chen, P.-T.: Atmospheric dry plus wet deposition and wet-only deposition of dicarboxylic acids and inorganic compounds in a coastal suburban environment, Atmos. Environ., 89, 696-706, https://doi.org/10.1016/j.atmosenv.2014.03.013, 2014.

van Drooge, B. L. and Grimalt, J. O.: Particle size-resolved source apportionment of primary and secondary organic tracer compounds at urban and rural locations in Spain, Atmos. Chem. Phys., 15, 7735-7752, https://doi.org/10.5194/acp-157735-2015, 2015.

van Pinxteren, M., Fiedler, B., van Pinxteren, D., Iinuma, Y., Körtzinger, A., and Herrmann, H.: Chemical characterization of sub-micrometer aerosol particles in the tropical Atlantic Ocean: marine and biomass burning influences, J. Atmos. Chem., 72, 105-125, https://doi.org/10.1007/s10874-015-9307-3, 2015.

Vasconcellos, P. C., Souza, D. Z., Sanchez-Ccoyllo, O., Bustillos, J. O., Lee, H., Santos, F. C., Nascimento, K. H., Araujo, M. P., Saarnio, K., Teinila, K., and Hillamo, R.: Determination of anthropogenic and biogenic compounds on atmospheric aerosol collected in urban, biomass burning and forest areas in Sao Paulo, Brazil, Sci. Total Environ., 408, 5836-5844, https://doi.org/10.1016/j.scitotenv.2010.08.012, 2010.

Wang, G., Xie, M., Hu, S., Gao, S., Tachibana, E., and Kawamura, K.: Dicarboxylic acids, metals and isotopic compositions of $\mathrm{C}$ and $\mathrm{N}$ in atmospheric aerosols from inland China: implications for dust and coal burning emission and secondary aerosol formation, Atmos. Chem. Phys., 10, 6087-6096, https://doi.org/10.5194/acp-10-6087-2010, 2010.

Wang, G., Chen, C., Li, J., Zhou, B., Xie, M., Hu, S., Kawamura, K., and Chen, Y.: Molecular composition and size distribution of sugars, sugar-alcohols and carboxylic acids in 
airborne particles during a severe urban haze event caused by wheat straw burning, Atmos. Environ., 45, 2473-2479, https://doi.org/10.1016/j.atmosenv.2011.02.045, 2011.

Wang, G., Kawamura, K., Cheng, C., Li, J., Cao, J., Zhang, R., Zhang, T., Liu, S., and Zhao, Z.: Molecular distribution and stable carbon isotopic composition of dicarboxylic acids, ketocarboxylic acids, and alpha-dicarbonyls in size-resolved atmospheric particles from Xi' an City, China, Environ. Sci. Technol., 46, 4783-4791, https://doi.org/10.1021/es204322c, 2012.

Wang, G., Kawamura, K., Xie, M., Hu, S., Li, J., Zhou, B., Cao, J., and An, Z.: Selected water-soluble organic compounds found in size-resolved aerosols collected from urban, mountain and marine atmospheres over East Asia, Tellus B, 63, 371-381, https://doi.org/10.1111/j.1600-0889.2011.00536.x, 2017.

Wang, J., Ge, C., Yang, Z., Hyer, E. J., Reid, J. S., Chew, B.-N., Mahmud, M., Zhang, Y., and Zhang, M.: Mesoscale modeling of smoke transport over the Southeast Asian Maritime Continent: Interplay of sea breeze, trade wind, typhoon, and topography, Atmos. Res., 122, 486-503, https://doi.org/10.1016/j.atmosres.2012.05.009, 2013.

Wang, Y. Q., Zhang, X. Y., and Draxler, R. R.: TrajStat: GISbased software that uses various trajectory statistical analysis methods to identify potential sources from long-term air pollution measurement data, Environ. Modell Softw., 24, 938-939, https://doi.org/10.1016/j.envsoft.2009.01.004, 2009.

Warneck, P.: Multi-Phase Chemistry of C2 and C3 Organic Compounds in the Marine Atmosphere, J. Atmos. Chem., 51, 119159, https://doi.org/10.1007/s10874-005-5984-7, 2005.

Wasson, S. J., Linak, W. P., Gullett, B. K., King, C. J., Touati, A., Huggins, F. E., Chen, Y., Shah, N., and Huffman, G. P.: Emissions of chromium, copper, arsenic, and PCDDs/Fs from open burning of CCA-treated wood, Environ. Sci. Technol., 39, 88658876, https://doi.org/10.1021/es050891g, 2005.

Wonaschuetz, A., Sorooshian, A., Ervens, B., Chuang, P. Y., Feingold, G., Murphy, S. M., de Gouw, J., Warneke, C., and Jonsson, H. H.: Aerosol and gas re-distribution by shallow cumulus clouds: An investigation using airborne measurements, J. Geophys. Res.-Atmos., 117, D17202, https://doi.org/10.1029/2012jd018089, 2012.

Wonaschütz, A., Hersey, S. P., Sorooshian, A., Craven, J. S., Metcalf, A. R., Flagan, R. C., and Seinfeld, J. H.: Impact of a large wildfire on water-soluble organic aerosol in a major urban area: the 2009 Station Fire in Los Angeles County, Atmos. Chem. Phys., 11, 8257-8270, https://doi.org/10.5194/acp11-8257-2011, 2011.

Xian, P., Reid, J. S., Atwood, S. A., Johnson, R. S., Hyer, E. J., Westphal, D. L., and Sessions, W.: Smoke aerosol transport patterns over the Maritime Continent, Atmos. Res., 122, 469-485, https://doi.org/10.1016/j.atmosres.2012.05.006, 2013.
Xu, J., Tian, Y., Cheng, C., Wang, C., Lin, Q., Li, M., Wang, X., and Shi, G.: Characteristics and source apportionment of ambient single particles in Tianjin, China: The close association between oxalic acid and biomass burning, Atmos. Res., 237, 104843, https://doi.org/10.1016/j.atmosres.2020.104843, 2020.

Xue, H., Khalizov, A. F., Wang, L., Zheng, J., and Zhang, R.: Effects of dicarboxylic acid coating on the optical properties of soot, Phys. Chem. Chem. Phys., 11, 7869-7875, https://doi.org/10.1039/b904129j, 2009.

Yamasoe, M. A., Artaxo, P., Miguel, A. H., and Allen, A. G.: Chemical composition of aerosol particles from direct emissions of vegetation fires in the Amazon Basin: water-soluble species and trace elements, Atmos. Environ., 34, 1641-1653, https://doi.org/10.1016/s1352-2310(99)00329-5, 2000.

Yang, H., Yu, J. Z., Ho, S. S. H., Xu, J., Wu, W.-S., Wan, C. H., Wang, X., Wang, X., and Wang, L.: The chemical composition of inorganic and carbonaceous materials in $\mathrm{PM}_{2.5}$ in Nanjing, China, Atmos. Environ., 39, 3735-3749, https://doi.org/10.1016/j.atmosenv.2005.03.010, 2005.

Yao, X., Fang, M., and Chan, C. K.: Size distributions and formation of dicarboxylic acids in atmospheric particles, Atmos. Environ. 36, 2099-2107, https://doi.org/10.1016/s1352-2310(02)002303, 2002.

Yao, X., Lau, A. P. S., Fang, M., Chan, C. K., and Hu, M.: Size distributions and formation of ionic species in atmospheric particulate pollutants in Beijing, China: 2 - dicarboxylic acids, Atmos. Environ., 37, 3001-3007, https://doi.org/10.1016/s13522310(03)00256-5, 2003.

Yu, J. Z., Huang, X.-F., Xu, J., and Hu, M.: When Aerosol Sulfate Goes Up, So Does Oxalate: Implication for the Formation Mechanisms of Oxalate, Environ. Sci. Technol., 39, 128-133, https://doi.org/10.1021/es049559f, 2005.

Yuan, H., Wang, Y., and Zhuang, G.: MSA in Beijing aerosol, Chinese Sci. Bull., 49, 1020-1025, https://doi.org/10.1007/bf03184031, 2004.

Zeng, G., Kelley, J., Kish, J. D., and Liu, Y.: Temperature-dependent deliquescent and efflorescent properties of methanesulfonate sodium studied by ATR-FTIR spectroscopy, J. Phys. Chem. A, 118, 583-591, https://doi.org/10.1021/jp405896y, 2014.

Ziemba, L. D., Griffin, R. J., Whitlow, S., and Talbot, R. W.: Characterization of water-soluble organic aerosol in coastal New England: Implications of variations in size distribution, Atmos. Environ., 45, 7319-7329, https://doi.org/10.1016/j.atmosenv.2011.08.022, 2011.

Zuo, Y.: Kinetics of photochemical/chemical cycling of iron coupled with organic substances in cloud and fog droplets, Geochim. Cosmochim. Ac., 59, 3123-3130, https://doi.org/10.1016/00167037(95)00201-A, 1995. 